\title{
A bivalent EBV vaccine induces neutralizing antibodies that block B and epithelial cell infection and confer immunity in humanized mice
}

Chih-Jen Wei ${ }^{1,2^{*}}$, Wei Bu ${ }^{3 *}$, Laura A. Nguyen ${ }^{1 *}$, Joseph D. Batchelor ${ }^{4}$, JungHyun $\mathrm{Kim}^{3}$, Stefania Pittaluga $^{5}$, James R. Fuller ${ }^{4 \S}$, Hanh Nguyen ${ }^{3}$, Te-Hui Chou ${ }^{1,2}$, Jeffrey I. Cohen ${ }^{3 \dagger}$, Gary J. Nabel ${ }^{1,2 \dagger}$

\author{
${ }^{1}$ Sanofi, \\ 640 Memorial Dr., Cambridge, MA.01239 \\ ${ }^{2}$ ModeX Therapeutics Inc. \\ 22 Strathmore Rd., Natick, MA 07160
}
${ }^{3}$ Laboratory of Infectious Diseases, National Institute of Allergy and Infectious Diseases, National Institute of Health.
50 South Dr., Bethesda, MD. 20892
${ }^{4}$ Integrated Drug Discovery, Sanofi, Waltham, MA.02451

${ }^{5}$ Laboratory of Pathology, Center for Cancer Research, National Cancer Institute, National Institutes of Health, Bethesda, MD 20892

* These authors contributed equally to this work.

${ }^{\dagger}$ To whom correspondence should be addressed: Gary J. Nabel (gary.nabel@modextx.com); Jeffrey I. Cohen (jcohen@,niaid.nih.gov)

$\S$ Current address: Omega Therapeutics, Cambridge, MA (L. Nguyen);_Department of Biochemistry and Molecular Biology, University of Chicago, Chicago, IL (J. R. Fuller)

One sentence summary: A bivalent gp350 and gH/gL/gp42 nanoparticle vaccine elicits neutralizing antibodies that protect against EBV infection and EBV lymphoma in vivo. 


\section{ABSTRACT}

Epstein Barr virus (EBV) is the major cause of infectious mononucleosis and is associated with several human cancers. Despite its prevalence and major impact on human health, there are currently no specific vaccines or treatments. Four viral glycoproteins, gp 350 and $\mathrm{gH} / \mathrm{gL} / \mathrm{gp} 42$ mediate entry into the major sites of viral replication, $B$ cells and epithelial cells. Here, we designed a nanoparticle vaccine displaying these proteins and show that it elicits potent neutralizing antibodies that protect against infection in vivo. Based on structural analyses, we designed single chain $\mathrm{gH} / \mathrm{gL}$ and $\mathrm{gH} / \mathrm{gL} / \mathrm{gp} 42$ proteins that were each fused to bacterial ferritin to form a self-assembling nanoparticles. X-ray crystallographic analysis revealed that single chain $\mathrm{gH} / \mathrm{gL}$ and $\mathrm{gH} / \mathrm{gL} / \mathrm{gp42}$ adopted a similar conformation to the wild type proteins, and the protein spikes were observed by electron microscopy. Single chain $\mathrm{gH} / \mathrm{gL}$ or $\mathrm{gH} / \mathrm{gL} / \mathrm{gp} 42$ nanoparticle vaccines were constructed to ensure product homogeneity needed for clinical development. These vaccines elicited neutralizing antibodies in mice, ferrets, and non-human primates that inhibited EBV entry into both B cells and epithelial cells. When mixed with a previously reported gp350 nanoparticle vaccine, $\operatorname{gp350D}_{123}$, no immune competition was observed. To confirm its efficacy in vivo, humanized mice were challenged with EBV after passive transfer of IgG from mice vaccinated with control, gH/gL/gp42+gp350D $D_{123}$ or $\mathrm{gH} / \mathrm{gL}+\mathrm{gp350D}_{123}$ nanoparticles. While all control animals (6/6) were infected, only one mouse in each vaccine group that received immune IgG had transient low level viremia (1/6). Furthermore, no EBV lymphomas were detected in immune animals in contrast to non-immune controls. This bivalent EBV nanoparticle vaccine represents a promising candidate to prevent EBV infection and EBV-related malignancies in humans. 


\section{INTRODUCTION}

Over $95 \%$ of adults worldwide are infected with Epstein-Barr virus (EBV), the primary

26

27 agent for infectious mononucleosis (IM) (1). EBV was discovered in the 1960s and was the first human virus associated with cancer; EBV has since been associated with malignancies such as nasopharyngeal carcinoma, Hodgkin's lymphoma, non-Hodgkin's lymphoma, Burkitt's lymphoma, NK/T cell lymphomas, peripheral T-cell lymphomas and gastric cancer $(1,2)$. Each year, more than 200,000 cases of cancer are associated with EBV infection, resulting in $\sim 140,000$ deaths (2). EBV is also the main cause of lymphoproliferative disease in patients with immunodeficiencies. Nearly all post-transplant lymphoproliferative disorder (PTLD) in the first year after is caused by EBV (3).

There is currently no therapy to effectively treat EBV infection, and there is no vaccine to prevent EBV infection. Prior vaccine development attempts mainly focused on one of the viral envelope glycoproteins gp350 as it is the most abundant surface protein and is the major target of neutralizing antibodies (4). gp350 mediates viral entry to B cells by engaging complement receptor 2 (CR2/CD21) (5). Other viral surface glycoproteins, namely gH, gL, gB, gp42 and BMRF2 also play a role in EBV infection and are also targets of neutralizing antibodies. gp42 binds to human leukocyte antigen (HLA) class II and together with $\mathrm{gH} / \mathrm{gL}$ heterodimer and $\mathrm{gB}$ forms a complex that promotes EBV entry to B cells (6). Infection of EBV to epithelial cells is initiated by the engagement of BMRF2 and gH/gL complex with integrin receptors and ephrin receptor A2 (7-9). A prototype gp 350 vaccine reduced the incidence of IM by $78 \%$, but did not prevent infection in a phase II clinical trial (10). Other gp350-based vaccines have also shown protective efficacy in relevant nonhuman primate models $(7,11,12)$. Recombinant $\mathrm{gH} / \mathrm{gL}$ complex or $\mathrm{gB}$ have also been shown to induce neutralizing antibody responses in rabbits (13). We have previously shown that 
47 a nanoparticle (NP)-based gp350 vaccine elicited protective immunity (14), and $\mathrm{gH} / \mathrm{gL}$ and $48 \mathrm{gH} / \mathrm{gL} / \mathrm{g} 42 \mathrm{NP}$ vaccines induced potent neutralizing antibodies that inhibit EBV entry in both B 49 cells and epithelial cells (15). In this study, we optimized the consistency of $\mathrm{gH} / \mathrm{gL}$ and $50 \mathrm{gH} / \mathrm{gL} / \mathrm{gp} 42$ that could reduce the heterogeneity of these heteromeric proteins by generating a

51 single chain polypeptide based on structural biology. This approach not only preserved the 52 presentation of these antigens but also ensured that the $\mathrm{gH} / \mathrm{gL}$ and gp42 heteromers were uniformly assembled to improve product consistency required for clinical grade vaccines. Here, we have evaluated the structure, immunogenicity and protection of single chain gH/gL-NP or single chain $\mathrm{gH} / \mathrm{gL} / \mathrm{gp} 42-\mathrm{NP}$ together with gp350-NP in relevant animal models.

\section{RESULTS}

Design and characterization of single chain $\mathrm{gH} / \mathrm{gL}$ and gH/gL/gp42 nanoparticles

When co-transfection of plasmids is used to generate multimeric complexes (15), there is potential inconsistency in the product if the appropriate stoichiometry is not achieved. To address this concern, we generated single chain $\mathrm{gH} / \mathrm{gL}$ or $\mathrm{gH} / \mathrm{gL} / \mathrm{gp} 42$ complexes using structural data to

62 fuse the ectodomains with flexible linkers (Fig. 1A). Fusion to specific sites on ferritin (14) facilitated the formation of self-assembling nanoparticles (NP). The $\mathrm{gH} / \mathrm{gL}$ and $\mathrm{gH} / \mathrm{gL} / \mathrm{gp} 42$

64 fusion proteins migrated as a single band on SDS-PAGE gel (Fig. S1). Crystal structures of single chain $\mathrm{gH} / \mathrm{gL}$ and single chain $\mathrm{gH} / \mathrm{gL} / \mathrm{gp} 42$ were determined (Fig. 1B; Supplemental Table 1). Each structure superimposed on previously published heterodimeric $\mathrm{gH} / \mathrm{gL}$ (PDB 3PHF) and heterotrimeric $\mathrm{gH} / \mathrm{gL} / \mathrm{gp} 42$ (PDB 5T1D) complex structures, respectively, demonstrating that single chain $\mathrm{gH} / \mathrm{gL}$ and single chain $\mathrm{gH} / \mathrm{gL} / \mathrm{gp} 42$ adopt native conformations resembling the wild- 
and size-exclusion chromatography (Fig. 1C, left), and dynamic light scattering analysis documented the expected particle radius of $20.7 \mathrm{~nm}$ and $24.8 \mathrm{~nm}$ for single chain $\mathrm{gH} / \mathrm{gL}-\mathrm{NP}$ and single chain gH/gL/gp42-NP, respectively (Fig 1C, right). The single chain gH/gL-NP and single chain $\mathrm{gH} / \mathrm{gL} / \mathrm{gp} 42-\mathrm{NP}$ were also visualized by transmission electron microscopy, showing visible spikes protruding from the ferritin core, consistent with the expected structure and stoichiometry (Fig. 1D, left and right panels respectively).

\section{Immunogenicity of single chain gH/gL-NP or gH/gL/gp42-NP in mice}

The immunogenicity of single chain gH/gL-NP was first evaluated in mice with or without AF03, a squalene-based oil-in-water emulsion adjuvant previously used in a pandemic influenza vaccine (16). The anti-gH/gL antibody titer was significantly higher in the adjuvanted group after each immunization (Supplemental Fig. 2, p<0.0001). All subsequent animal studies were therefore carried out in the presence of AF03 adjuvant. Single chain gH/gL-NP elicited a robust antibody response against the $\mathrm{gH} / \mathrm{gL}$ complex and when used together with the previously described gp350D ${ }_{123}-\mathrm{NP}(14)$, no immune competition was seen (Supplemental Fig. 3). Similar results were observed when gp42 was included to generate a single chain gH/gL/gp42-NP that induced antibodies against both gH/gL and gp42 after immunization (Supplemental Fig. 4A). Again, no immune competition was observed when mice were given a bivalent single chain-gH/gL/gp42-NP and gp350D ${ }_{123}-\mathrm{NP}$ vaccine as the antibodies titers against each individual antigen remained at the similar levels (Supplemental Fig. 4B). The neutralizing activity of sera from animals immunized with single chain $\mathrm{gH} / \mathrm{gL}-\mathrm{NP}$ and single chain $\mathrm{gH} / \mathrm{gL} / \mathrm{gp} 42-\mathrm{NP}$ were evaluated in both $\mathrm{B}$ cells and epithelial cells (Fig 2). Single chain gH/gL-NP, gH/gL/gp42-NP and gp350D $123-N P$ all elicited potent neutralizing antibodies that blocked virus entry to $\mathrm{B}$ cells, and the neutralizing $\mathrm{IC}_{50}$ titers remained at similar or higher levels when single chain gH/gL-NP or single chain $\mathrm{gH} / \mathrm{gL} / \mathrm{gp} 42-\mathrm{NP}$ 
was mixed with gp350 $\mathrm{D}_{123}-\mathrm{NP}$ in a bivalent vaccine (Fig. $2 \mathrm{~A}, 2 \mathrm{~B}$, left, $\mathrm{p}<0.05$ compared to control). Virus neutralization in epithelial cells was also evident in mice that received single chain gH/gL-NP and single chain $\mathrm{gH} / \mathrm{gL} / \mathrm{gp} 42-\mathrm{NP}$ while gp350 ${ }_{123}-\mathrm{NP}$ antiserum had minimum effect in blocking EBV infection in epithelial cells, consistent with our previous report (15) (Fig. 2A, right, $\mathrm{p}<0.05$ compared to control). Again, bivalent single chain $\mathrm{gH} / \mathrm{gL}-\mathrm{NP}+\mathrm{gp} 350 \mathrm{D}_{123} \mathrm{NP}$ or single chain $\mathrm{gH} / \mathrm{gL} / \mathrm{gp} 42-\mathrm{NP}+\mathrm{gp} 350 \mathrm{D}_{123}-\mathrm{NP}$ induced similar neutralizing antibody titers as the monovalent single chain gH/gL-NP and single chain gH/gL/gp42-NP, respectively (Fig. 2A, 2B, right, $\mathrm{p}<0.05$ compared to control).

\section{Bivalent single chain $\mathrm{gH} / \mathrm{gL}-\mathrm{NP}+\mathrm{gp350D}_{123}-\mathrm{NP}$ or single chain $\mathrm{gH} / \mathrm{gL} / \mathrm{gp} 42-\mathrm{NP}+\mathrm{gp350D}_{123}-$} NP elicited neutralizing antibodies in ferrets and non-human primates

We next evaluated the immunogenicity of bivalent single chain $\mathrm{gH} / \mathrm{gL}-\mathrm{NP}+\mathrm{gp} 350 \mathrm{D}_{123}-\mathrm{NP}$ and single chain $\mathrm{gH} / \mathrm{gL} / \mathrm{gp} 42-\mathrm{NP}+\mathrm{gp} 350 \mathrm{D}_{123}-\mathrm{NP}$ in EBV-naïve ferrets. Non-immune ferrets were immunized with 2 doses of single chain gH/gL-NP+gp350D ${ }_{123}-\mathrm{NP}$ or single chain $\mathrm{gH} / \mathrm{gL} / \mathrm{gp} 42-$ $\mathrm{NP}+\mathrm{gp} 350 \mathrm{D}_{123}-\mathrm{NP}$ at weeks 0 and 4 . Immune sera from ferrets receiving single chain $\mathrm{gH} / \mathrm{gL} / \mathrm{gp} 42-\mathrm{NP}+\mathrm{gp} 350 \mathrm{D}_{123}-\mathrm{NP}$ elicited more potent neutralizing antibodies that inhibit virus entry to B cells than animals immunized with single chain $\mathrm{gH} / \mathrm{gL}-\mathrm{NP}+\mathrm{gp} 350 \mathrm{D}_{123}-\mathrm{NP}$ (Fig 3A, left, $\mathrm{p}<0.05$ compared to pre-immune sera). In epithelial cells, both single chain $\mathrm{gH} / \mathrm{gL}-$ $\mathrm{NP}+\mathrm{gp} 350 \mathrm{D}_{123}-\mathrm{NP}$ and single chain $\mathrm{gH} / \mathrm{gL} / \mathrm{gp} 42-\mathrm{NP}+\mathrm{gp} 350 \mathrm{D}_{123}-\mathrm{NP}$ anti-sera showed high titers of antibodies that neutralized EBV infection (Fig 3A, right, $\mathrm{p}<0.05$ compared to pre-immune sera). These findings were confirmed by measuring ELISA binding of antibodies to each component elicited by each bivalent vaccine (Supplemental Fig. $5,{ }^{* *} \mathrm{p}<0.0001$ or ${ }^{*} \mathrm{p}<0.05$ respectively compared to pre-immune sera). Background reactivity observed in pre-immune ferret sera likely represented non-specific binding of the secondary anti-ferret antibody as it was not observed in 
116 the neutralization assay. Despite this background, antibody levels increased 9-400-fold after 117 immunization.

A high percentage of rhesus macaques are infected naturally during infancy with rhesus

119 lymphocryptovirus (rhLCV), a herpesvirus closely related and immunologically cross-reactive with EBV (17). To determine whether vaccination could boost pre-existing immune responses,

121 we immunized rhesus macaques (Macaca mulatta) with single chain gH/gL-NP+gp350D $123-\mathrm{NP}$

122 or single chain $\mathrm{gH} / \mathrm{gL} / \mathrm{gp} 42-\mathrm{NP}+\mathrm{gp} 350 \mathrm{D}_{123}-\mathrm{NP}$ to model immune responses in humans. After the

123 third immunization, serum neutralization titers in animals receiving single chain $\mathrm{gH} / \mathrm{gL}$ $124 \mathrm{NP}+\mathrm{gp} 350 \mathrm{D}_{123}-\mathrm{NP}$ or single chain $\mathrm{gH} / \mathrm{gL} / \mathrm{gp} 42-\mathrm{NP}+\mathrm{gp} 350 \mathrm{D}_{123}-\mathrm{NP}$ were substantially elevated 125 compared to the pre-immune sera (Fig 3B, left; 10,000-fold for single chain $\mathrm{gH} / \mathrm{gL}$ $126 \mathrm{NP}+\mathrm{gp} 350 \mathrm{D}_{123}-\mathrm{NP}$ and $>2,000$-fold for single chain $\mathrm{gH} / \mathrm{gL} / \mathrm{gp} 42-\mathrm{NP}+\mathrm{gp} 350 \mathrm{D}_{123}-\mathrm{NP}, * \mathrm{p}<0.05$

127 compared to pre-immune sera). As expected, substantial reactivity was observed in pre-immune 128 sera (Supplemental Fig. 6, top and bottom left), likely due to the high amino acid sequence identity 129 between EBV and rhLCV gH (85.4\%), gL (81.8\%) and gp42 (88\%) (17). Similar to the preexisting anti-gH/gL and anti-gH/gL/gp42 binding antibodies, neutralizing activity was observed 131 in epithelial cells with the pre-immune monkey sera. Nonetheless, the neutralizing antibody titers 132 increased by more than 20 - and $\sim 7$-fold after the third immunization with single chain $\mathrm{gH} / \mathrm{gL}$ $133 \mathrm{NP}+\mathrm{gp} 350 \mathrm{D}_{123}-\mathrm{NP}$ and single chain $\mathrm{gH} / \mathrm{gL} / \mathrm{gp} 42-\mathrm{NP}+\mathrm{gp} 350 \mathrm{D}_{123}-\mathrm{NP}$, respectively (Fig. 3B, right) 134 and the activity was maintained for at least 12 weeks (data not shown). These findings were 135 confirmed by measuring ELISA binding titers to $\mathrm{gH} / \mathrm{gL}$ and $\mathrm{gH} / \mathrm{gL} / \mathrm{gp} 42$. In contrast, little 136 reactivity to gp350D 123 was observed in pre-immune sera because the homology between EBV 137 and rhLCV gp350 is much lower (49\%) (Supplemental Fig 6, top and bottom right). gp350 is 138 important for EBV attachment to $\mathrm{B}$ cells before the $\mathrm{gH} / \mathrm{gL} / \mathrm{gp} 42$ complex initiates membrane 
fusion and is likely the reason why there was minimal difference in neutralization between B and epithelial cells. Regardless of prior immunity, anti-gH/gL, anti-gH/gL/gp42 and anti-gp350 antibody titers all increased after immunization (Supplemental Fig $6, * * p<0.0001$ or $* p<0.01$ respectively compared to pre-immune sera). These data confirmed the immunogenicity of bivalent single chain $\mathrm{gH} / \mathrm{gL}-\mathrm{NP}+\mathrm{gp} 350 \mathrm{D}_{123}-\mathrm{NP}$ and single chain $\mathrm{gH} / \mathrm{gL} / \mathrm{gp} 42-\mathrm{NP}+\mathrm{gp} 350 \mathrm{D}_{123}-\mathrm{NP}$ vaccines and indicate that neutralizing antibodies were induced by these vaccines in nonhuman primates. Although there is variation in antibody titers elicited by the bivalent vaccine in different models, our data clearly demonstrate that neutralizing antibodies could be readily elicited by the bivalent vaccines described in both naïve and EBV-immune animal models.

\section{Bivalent single chain $\mathrm{gH} / \mathrm{gL}-\mathrm{NP}+\mathrm{gp350D}_{123}-\mathrm{NP}$ or single chain $\mathrm{gH} / \mathrm{gL} / \mathrm{gp} 42-\mathrm{NP}+\mathrm{gp350D}_{123}-$}

\section{NP immune sera protected humanized mice from EBV infection and lymphoma}

To assess the protective efficacy of single chain $\mathrm{gH} / \mathrm{gL}-\mathrm{NP}+\mathrm{gp} 350 \mathrm{D}_{123}-\mathrm{NP}$ and single chain $\mathrm{gH} / \mathrm{gL} / \mathrm{gp} 42-\mathrm{NP}+\mathrm{gp} 350 \mathrm{D}_{123}-\mathrm{NP}$ vaccines, we performed an EBV challenge study using a humanized mouse model. Engraftment of human CD34+ hematopoietic stem cells into NOD-scid IL2 $\mathrm{rg}^{-/ /}$mice (CD34+ huNSG) allows for the reconstitution of human immune system components and these mice can be infected with EBV (18-21). Purified IgG from naïve (control), single chain

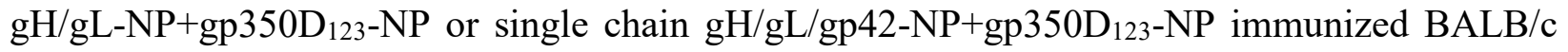
mice were passively transferred to three groups of CD34+ huNSG mice on days $-1,0$ and +1 and mice were challenged intravenously with EBV on day 0. All animals in the control group had viremia while only one animal each receiving IgG from single chain $\mathrm{gH} / \mathrm{gL}-\mathrm{NP}+\mathrm{gp} 350 \mathrm{D}_{123}-\mathrm{NP}$ or

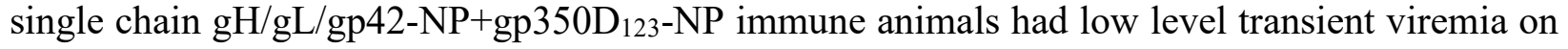
one day, further demonstrating the protective efficacy conferred by single chain $\mathrm{gH} / \mathrm{gL}$ $\mathrm{NP}+\mathrm{gp} 350 \mathrm{D}_{123}-\mathrm{NP}$ and single chain $\mathrm{gH} / \mathrm{gL} / \mathrm{gp} 42-\mathrm{NP}+\mathrm{gp} 350 \mathrm{D}_{123}-\mathrm{NP}$ vaccines $($ Fig. $4 \mathrm{~A}, \mathrm{p}<0.05$ at 
week 5 and week 9). In situ hybridization for EBV encoded RNA 1 (EBER1) showed viral RNA in tissue of 4 of 6 animals receiving control $\mathrm{IgG}$, while tissues from all animals in the other two groups were entirely negative for EBER1 (Fig. 4B, p<0.005). Three of the six animals that received control IgG had EBV positive B cell lymphomas, while none of the animals that received IgG from either single chain $\mathrm{gH} / \mathrm{gL}-\mathrm{NP}+\mathrm{gp} 350 \mathrm{D}_{123}-\mathrm{NP}$ or single chain $\mathrm{gH} / \mathrm{gL} / \mathrm{gp} 42$ NP+gp350D ${ }_{123}-\mathrm{NP}$ immune animals developed lymphoma (Fig. 5 and Supplemental Fig. 7, $\mathrm{p}<0.05$ ). We also determined the levels of anti-gH/gL, anti-gH/gL/gp42 and anti-gp350 in animals 1 week after challenge using an immunoprecipitation assay, and the antibody levels against gp350, $\mathrm{gH} / \mathrm{gL}$ and gp42 were comparable to those from animals immunized with 2 doses of EBV vaccines in previous studies, ranging from $10^{5}$ to $10^{6}$ relative light units (Supplemental Fig. 8) $(14,15)$.

\section{DISCUSSION}

An effective vaccine could reduce the burden of a variety of diseases associated with EBV infection, including infectious mononucleosis and a wide range of B cell and epithelial cell cancers. A previous phase 2 trial with an EBV gp350 vaccine reduced rate of infectious mononucleosis, but failed to induce sterilizing immunity in clinic (10), suggesting that additional immunogens that target viral entry to epithelial cells may be required for a successful prophylactic vaccine $(15,22)$. While EBV gp350 is important for attachment of the virus to B cells, it is not required for infection in vitro; in contrast, EBV gH, gL and gp42 are all essential for infection and EBV fusion to host cells. Here, we rationally designed vaccine candidates based on knowledge of their structural biology that allow expression of $\mathrm{gH} / \mathrm{gL}$ and $\mathrm{gH} / \mathrm{gL} / \mathrm{gp} 42$ in a nanoparticle as a single polypeptide. This approach ensures the proper formation of 1:1 heterodimers for $\mathrm{gH} / \mathrm{gL}$ and 1:1:1 heterotrimers for $\mathrm{gH} / \mathrm{gL} / \mathrm{gp} 42$, respectively. These single 
185

186

187

188

189

190

191

192

193

194

195

196

197

198

199

200

201

202

203

204

205

206 207 lymphoma in vivo.

chain recombinant proteins can be easily purified and the conformation of the $\mathrm{gH} / \mathrm{gL}$ and $\mathrm{gH} / \mathrm{gL} / \mathrm{gp} 42$ nanoparticles remains intact compared with nanoparticles produced from

combinations of polypeptides as determined by x-ray crystallography. The ability to express the $\mathrm{gH} / \mathrm{gL}$ or $\mathrm{gH} / \mathrm{gL} / \mathrm{gp} 42$ nanoparticles as single polyproteins reduces the number of components required to generate the vaccines and enables greater control of product homogeneity that facilitates scaled manufacturing.

Immunization of mice with single chain $\mathrm{gH} / \mathrm{gL}-\mathrm{NP}$ or single chain $\mathrm{gH} / \mathrm{gL} / \mathrm{gp} 42-\mathrm{NP}$ induced high titers of antibodies that neutralized EBV entry to B cells and epithelial cells. Addition of a structurally optimized, truncated gp350, gp350D ${ }_{123}-\mathrm{NP}$ (14), to single chain gH/gL-NP or single chain gH/gL/gp42-NP stimulated effective gp350 directed Abs without reducing $\mathrm{gH} / \mathrm{gL}$ or $\mathrm{gH} / \mathrm{gL} / \mathrm{gp} 42$ responses as shown previously for gp350D $123-\mathrm{NP}$ and $\mathrm{gH} / \mathrm{gL}-\mathrm{NP}$ or $\mathrm{gH} / \mathrm{gL} / \mathrm{gp} 42-\mathrm{NP}$ (15), suggesting that a bivalent vaccine formulation with both gp350 and $\mathrm{gH} / \mathrm{gL} / \mathrm{gp} 42$ components would provide improved coverage against the virus on different cell types. These neutralizing antibody responses were observed in ferrets, an EBV-naïve mammalian species. Importantly, in monkeys with pre-existing cross-reactive immunity to EBV due to prior infection by rhLCV, substantially higher titers of neutralizing antibodies were induced by immunization with these bivalent vaccines. In mice and NHPs, both single chain $\mathrm{gH} / \mathrm{gL}-\mathrm{NP}+$ gp350D $123-\mathrm{NP}$ and gH/gL/gp42-NP + gp350D ${ }_{123}-\mathrm{NP}$ bivalent vaccines induced neutralizing antibodies that inhibited EBV entry in B cells and epithelial cells. The neutralizing antibody levels ( $\mathrm{IC}_{50}$ titers) elicited by the bivalent vaccines were similar to those seen previously with combined $\mathrm{gH} / \mathrm{gL} / \mathrm{gp} 42+$ gp350 nanoparticle vaccines in other formats (15). Importantly, we show here that this immunity also protects against EBV infection and development of EBV 
Evaluation of the protective efficacy of EBV vaccines is challenging as humans are the

209

210

211

212

213

214

215

216

217

218

219

220

221

222

223

224

225

226

227

228

229

230

only natural reservoir for EBV. There are limitations in the animal models to evaluate EBV

vaccine efficacy because EBV does not naturally infect rodents (1). In contrast, rhesus macaques

are naturally infected almost universally by rhesus lymphocryptovirus (rhLCV) which is

homologous to EBV; each of the rhLCV glycoproteins has an ortholog in EBV and antibodies to

the rhLCV glycoproteins complicate EBV challenge studies. Furthermore, it is extremely

difficult to obtain sufficient rhLCV seronegative NHPs for vaccination and challenge studies.

Although vaccinated common marmosets have reduced EBV DNA in buccal fluid after EBV

challenge (23), reduced shedding in oral fluids is not a useful test for efficacy of a vaccine. In

addition, these animals are naturally infected with a marmoset homolog of EBV (Callitrichine

herpesvirus 3) which has orthologs of EBV gH/gL/gp42 and gp350; thus, most common

marmosets have antibodies to these glycoproteins that confound challenge studies. Finally,

while rabbits can be infected with EBV, it requires non-physiologic, extremely high doses (20-80

million copies of EBV) of virus to infect them (24).

Several laboratories have modeled EBV infection in humanized mice engrafted with

CD34+ hematopoietic progenitor cells isolated from umbilical cord blood (CD34+ huNSG) (28)

and have shown that these animals become viremic after infection (20). Here we used this model

to validate protection against EBV viremia using our bivalent EBV vaccines by passive transfer

of immune IgG from vaccinated mice. Nearly all CD34+ huNSG mice that received purified

IgG from bivalent vaccinated animals displayed undetectable viremia after EBV challenge; in

contrast, $10^{2}-10^{3}$ copies of EBV DNA/10 $\mu$ l of blood were present in animals that received

control IgG. Successful protection was conferred by passive transfer of vaccine-induced

antibodies. Because it is technically not possible to perform active immunization in a relevant 
231

232

233

234

235

236

237

238

239

240

241

242

243

244

245

246

247

248

249

250

251

252

253

254

44

model of infection, we showed here that transfer of IgG obtained from serum alone conferred protection, demonstrating both the efficacy and mechanism of immune protection at the same time. There is ample precedent for the use of passive transfer to demonstrate vaccine-induced immune protection for other viruses (25-27). Similar to our previous report (15), both single chain $\mathrm{gH} / \mathrm{gL}-\mathrm{NP}$ and $\mathrm{gH} / \mathrm{gL} / \mathrm{gp} 42-\mathrm{NP}$ induced robust antibody responses that neutralized EBV entry to B cells and epithelial cells. The rationale to include gp42 is to mimic the natural heterotrimeric viral structure of the $\mathrm{gH} / \mathrm{gL} / \mathrm{gp} 42$ complex. This complex has been implicated in mediating B cell neutralization (4) and will be the lead candidate moving forward. Our approach ensures correct complex stoichiometry, simplifies protein production, minimizes heterogeneity, improves immunogen stability, and reduces manufacturing costs. Taken together, these data suggest that the single chain $\mathrm{gH} / \mathrm{gL} / \mathrm{gp} 42$ and gp350 bivalent vaccine represents an efficient, scalable candidate vaccine that is likely to limit viremia after EBV infection, thereby reducing infectious mononucleosis and possibly EBV associated cancers.

\section{MATERIALS AND METHODS}

\section{Vector Construction.}

The EBV glycoproteins gH, gL and gp42 amino acid sequences were obtained from

NCBI GenPept with the following accession numbers: gH (Q3KSQ3.1), gL(P03212.1) and gp42

(P0C6Z5.1). Through structural modeling, the glycoproteins were fused via a flexible amino acid

linker to make a single chain $\mathrm{gH} / \mathrm{gL}$ heterodimer or $\mathrm{gH} / \mathrm{gL} / \mathrm{gp} 42$ heterotrimer recombinant

protein (Supplementary Table 2). A 6-histidine tag with a thrombin cleavage sequence was

placed at the C-terminus of the single chain recombinant protein for affinity purification

purposes. The EBV nanoparticle glycoproteins were generated by fusing the singe-chain

glycoproteins to the N-terminus of Helicobacter pylori- ferritin (14). 


\section{Recombinant protein expression and purification} approximately $10 \mathrm{mg} / \mathrm{mL}$ using $10 \mathrm{kDa}$ cutoff centrifugal filters. This material was then subjected equilibrated in TBS buffer $(20 \mathrm{mM}$ Tris $\mathrm{pH} 7.4,150 \mathrm{mM} \mathrm{NaCl})$. Peak fractions containing pure non-void fractions containing the fusion protein, but not PNGase F. These fractions were

272 chromatography $(20 \mathrm{mM}$ Tris- $\mathrm{HCl} \mathrm{pH} 7.5,50 \mathrm{mM} \mathrm{NaCl})$, followed by Superose 6 10/300gL size

273 exclusion chromatography filtration column in PBS (GE Healthsciences). SDS-PAGE and western

274 blots were performed to detect the presence of the nanoparticles (Biorad). Endotoxin analyses

275 ensured that all vaccine doses contained $<0.1$ EU per mouse.

\section{Crystallization and cryoprotection}


gH/gL/gp42 and 1M LiCl, 10\% PEG 6k, 0.1M Na ${ }_{3}$ Citrate pH 5.0 for single-chain gH/gL. Drops (200 $\mathrm{nL}$ total volume) were set up at a $1: 1$ ratio of protein stock $(7.5 \mathrm{mg} / \mathrm{mL})$ and crystallization solutions. Crystals were cryo-protected by transfer into a fresh drop of the crystallization solution supplemented to $25 \%$ glycerol and incubated for $10 \mathrm{~s}$ immediately prior to freezing in liquid $\mathrm{N}_{2}$. X-ray diffraction data for single chain $\mathrm{gH} / \mathrm{gL}$ were collected at the Advanced Photon Source beamline LS-CAT 21-ID-D and on an EigerX 9M Detector (wavelength 1.1 $\AA$ ). X-ray diffraction data for single chain $\mathrm{gH} / \mathrm{gL} / \mathrm{gp} 42$ were collected at Diamond Light Source beamline i24 on a Pilatus $36 \mathrm{M}$ detector (wavelength $0.9686 \AA$ ). Both datasets were indexed, integrated and scaled using XDS $(29,30)$. Initial phases were obtained by molecular replacement with Phaser $(31,32)$ using the $3 \mathrm{PHF}$ structure for single chain $\mathrm{gH} / \mathrm{gL}$ and the $\mathrm{gH} / \mathrm{gL} / \mathrm{gp} 42$ domains of 5W0K for single chain $\mathrm{gH} / \mathrm{gL} / \mathrm{gp} 42$. Structures were modeled and refined using the programs COOT (33) and PHENIX (34).

\section{Negative stain transmission electron microscopy}

$1 \mathrm{mg} / \mathrm{mL}$ of nanoparticle samples were sent to the Harvard Medical School Electron Microscopy Facility for negative stain transmission electron microscopy. The samples were stained with 0.75\% uranyl formate and a TecnaiG ${ }^{2}$ Spirit BioTWIN microscope was used to image the grids. The images were recorded with an AMT 2k charge-coupled device camera.

\section{Immunization}

Animal experiments were carried out in accordance with all federal regulations and were approved by the Sanofi Institutional Animal Care and Use Committee in fully AAALAC accredited facilities. Six- to eight-week old female BALB/c mice (Sanofi in house) were immunized $(n=5)$ intramuscularly with purified proteins either in the absence or presence of Sanofi Pasteur AF03 adjuvant at $50 \%(\mathrm{v} / \mathrm{v})$ formulation. $1 \mu \mathrm{g} \mathrm{gH} / \mathrm{gL}$ or $1 \mu \mathrm{g} \mathrm{gH} / \mathrm{gL} / \mathrm{gp} 42$ nanoparticles plus $1 \mu \mathrm{g}$ of 
naked ferritin nanoparticle vaccine were given intramuscularly to each mouse. The bivalent formulation comprised $1 \mu \mathrm{g} \mathrm{gH} / \mathrm{gL}$ or $1 \mu \mathrm{g} \mathrm{gH} / \mathrm{gL} / \mathrm{gp} 42$ nanoparticle plus $1 \mu \mathrm{g}$ gp350D 123 nanoparticle vaccine. Immunizations were given at weeks 0 and 3 . Sera were collected -2 days before immunization, and then at week 2,5 , and 8 post- immunizations. The animal studies with $\mathrm{gH} / \mathrm{gL}$ and $\mathrm{gH} / \mathrm{gL} / \mathrm{gp} 42$ were performed in separate, independent experiments. Given the limited amount of sera available from these mice, it was technically not possible to perform neutralization assays for a head-to-head comparison.

Ferrets and NHP studies were carried out in accordance with the recommendations of the Association for Assessment and Accreditation of Laboratory Animal Care International Standards and with the recommendations in the Guide for the Care and Use of Laboratory Animals of the United StatesNational Institutes of Health. The Institutional Animal Use and Care Committee of BIOQUAL approved these experiments. Ferrets (n=6/group) were injected intramuscularly with $15 \mu \mathrm{g} g \mathrm{H} / \mathrm{gL}$ or $15 \mu \mathrm{g} \mathrm{gH} / \mathrm{gL} / \mathrm{gp} 42$ nanoparticles plus $15 \mu \mathrm{g}$ gp350D 123 nanoparticle vaccine in the presence of Sanofi Pasteur AF03 adjuvant at 50\% (v/v) formulation at weeks 0 and 4. Sera were analyzed at weeks 0,2 , and 6. All rhesus macaques are considered rhLCV-seropositive as pre-immune sera showed high background against $\mathrm{gH} / \mathrm{gL}$ and $\mathrm{gH} / \mathrm{gL} / \mathrm{gp} 42$ and residual activity against gp350 (Supplemental Figure 6). Rhesus macaques (n=4/group) were injected intramuscularly with $25 \mu \mathrm{g}$ $\mathrm{gH} / \mathrm{gL}$ or $25 \mu \mathrm{g} \mathrm{gH} / \mathrm{gL} / \mathrm{gp} 42$ nanoparticles plus $25 \mu \mathrm{g}$ dose of gp350D 123 nanoparticle vaccine in the presence of Sanofi Pasteur AF03 adjuvant at 50\% (v/v) formulation at weeks 0, 4, and 10. Sera were analyzed at weeks $-1,2,6,8$, and 12 .

\section{Enzyme-linked immunosorbent assay}

Plates were coated with antigens at $100 \mathrm{ng} /$ well in PBS and incubated at $4{ }^{\circ} \mathrm{C}$ overnight. The plates were then washed five times in PBS-T and blocked with buffer containing 5\% milk (Difco \#232100) and 1\% BSA (Sigma \#A906-500G) in PBS-T (BioVision \#2310-100). Serial 
dilutions of serum were made in $2.5 \%$ milk and $0.5 \%$ BSA in PBS-T. The diluted sera were added to the plate and incubated for 1 hour at room temp before being washed five times in PBS-T. Antimouse-HRP secondary (GE NA931V), anti-NHP-HRP secondary (Invitrogen), or HRP anti-ferret IgG (LS Bio LS-C61236-1) were added to the plate, and incubated for 1 hour at room temperature. The plate was washed five times and Sure Blue Substrate (KPL \#52-00-00) was added at 100 $\mu \mathrm{L} /$ well. Once color was visualized, the reaction was stopped by adding $100 \mu \mathrm{L}$ of $1 \mathrm{~N} \mathrm{H}_{2} \mathrm{SO}_{4}$ and a Spectramax M5 plate reader was used to measure absorbency at $450 \mathrm{~nm}$.

\section{GFP reporter virus neutralization assay}

Immune sera from vaccinated mice, ferrets, or monkeys were serial diluted and incubated with B95-8/F EBV GFP-reporter virus for 2 hours. The mixture was added to Raji B cells, SVK CR2 or 293 epithelial cells and incubated for 3 days (15). Cells were then washed and fixed for flow cytometry to measure for GFP-positive cells

\section{Quantification of antibody titers in plasma by luciferase immunoprecipitation system assay}

EBV gp350, gH/gL, and gp42 antibody titers in the week 1 post EBV challenge plasma samples were measured by luciferase immunoprecipitation system (LIPS) assay as previously described (35, 36). Briefly, cell lysates expressing EBV gp350, gH/gL, or gp42 Renilla luciferase fusion proteins were incubated with plasma from week 1 post infection for $1 \mathrm{hr}$ and immunoprecipitated with protein $\mathrm{A} / \mathrm{G}$ beads for $1 \mathrm{hr}$. Coelenterazine substrate was added to each well and luciferase activity was measured in light units (LU) by a luminometer. Each sample was tested in duplicate. The inoculum for the passive transfer in vivo study, purified IgG from single chain $\mathrm{gH} / \mathrm{gL}-\mathrm{NP}+\mathrm{gp} 350 \mathrm{D}_{123}-\mathrm{NP}$ or single chain $\mathrm{gH} / \mathrm{gL} / \mathrm{gp} 42-\mathrm{NP}+\mathrm{gp} 350 \mathrm{D}_{123}-\mathrm{NP}$ immunized BALB/c mice, was serially diluted and used to generate a standard curve. Plasma from mice 1 week post $\mathrm{EBV}$ challenge that received purified $\mathrm{IgG}$ from naïve $\mathrm{BALB} / \mathrm{C}$ mice were included in 
each plate as a negative control. LU values that were in the linear range of a standard curve were converted to antibody titers in the plasma by interpolating a standard curve using GraphPad PRISM software.

\section{Passive transfer EBV challenge study}

354 NIH guidelines and were approved by the Animal Care and Use Committee of the National 355 Institute of Allergy and Infectious Diseases. Three groups of BALB/c mice ( $\mathrm{n}=80 /$ group) were 356 immunized with $5 \mu \mathrm{g} \mathrm{gH} / \mathrm{gL}$ or $5 \mu \mathrm{g} \mathrm{gH} / \mathrm{gL} / \mathrm{gp} 42$ nanoparticle plus $5 \mu \mathrm{g}$ dose of gp350D 123 in the 357 presence of AF03 adjuvant at weeks 0, 3 and 7 to induce an antibody response. Sera from each of 358 the vaccinated BALB/C groups were pooled at weeks 4, 5, 8, 9, and 10 for mouse IgG purification.

359 The control group was unimmunized BALB/c mice; similar non-immune sera have often been used as a negative control in previous publications $(37,38)$. Purified $\mathrm{mIgG}$ from each group was

361 passively transferred to CD34+ humanized NSG mice (Jackson Laboratory) intraperitoneally at

$36220 \mu \mathrm{g}$ of $\mathrm{mIgG}$ per gram of mouse at day -1 , day 0 , and day 1 . The mice were challenged 363 intravenously at day 0 with $10^{5}$ Green Raji Units of EBV. Mice were weighed weekly. EBV 364 viremia was measured using qPCR to detect the viral gene BamH1 W (39) in the blood at week $5,7,9,14$, and 18 .

\section{Dynamic light scattering}

368 Technology). The samples were diluted in PBS, adjusted to $0.01 \mathrm{mg} / \mathrm{mL}$ concentration for each 
Tissues from mice were collected 27 weeks after EBV challenge and fixed in 10\% neutrala riboprobe for EBV EBER1. Sections were coded and read by a pathologist in a blinded fashion. version 9.3.

378 Funding: this study was funded by Sanofi R\&D and the Intramural Research Program of the 379 National Institute of Allergy and Infectious Diseases.

Acknowledgements We thank all members of Sanofi Breakthrough Lab for insightful discussions throughout this study. We thank Hanne Andersen Elyard, Laurent Pessaint and Jake Yalley from Bioqual for assistance with Ferret and NHP studies. We thank Harvard Medical School Electron Microscopy Facility for negative stain transmission electron microscopy. We thank Amy Sullivan, Kelly Balko, and the Sanofi Comparative Medicine group for help with the mouse immunogenicity studies,

386 Author contributions: C.-J. W., W.B., L.A.N., J.I.C., and G.J.N. designed research studies; J.D.B., R.K., S.P.; J.R.F., J.I.C., and G.J.N. interpreted and discussed the data; C.-J. W., W.B., L.A.N., J.I.C., and G.J.N. wrote the paper and all authors participated in manuscript revisions. Competing interests: At the time the research described in this paper was initiated, L.A.N., C.applications on EBV vaccines. C.J.W. and G.J.N. are inventors of nanoparticle-based vaccines that have been filed by either Sanofi or the U.S. government. W.B and J.I.C. are current 
394 employees of U.S. government which has issued patents on ferritin-nanoparticle based EBV

395 vaccines.

396 Data and materials availability: All data is available in the main text or the supplementary 397 materials.

398 Supplementary Materials (on a separate file):

399 Materials and Methods

400 Figs. S1 to S9

401 Tables S1 to S2

402 
404

405

406

407

408

409

410

411

412

413

414

415

416

417

418

419

420

421

422

423

424 not reconstructed from EM.

Figure 1. Structure-based design of single chain $\mathrm{gH} / \mathrm{gL}$ and single chain $\mathrm{gH} / \mathrm{gL} / \mathrm{gp} 42$ nanoparticles. (A) A schematic representation of the single chain $\mathrm{gH} / \mathrm{gL}$, single chain $\mathrm{gH} / \mathrm{gL} / \mathrm{gp} 42$, single chain gH/gL-NP, and single chain $\mathrm{gH} / \mathrm{gL} / \mathrm{gp} 42-\mathrm{NP}$. EBV gL (green) is fused to the $\mathrm{N}$ terminus of $\mathrm{gH}$ (cyan) via a flexible amino acid linker (indicated by the black line between $\mathrm{gL}$ and $\mathrm{gH}$ ). EBV gp42 (gray) is fused to the C-terminus of gH. Single chain $\mathrm{gH} / \mathrm{gL}-\mathrm{NP}$ or single chain $\mathrm{gH} / \mathrm{gL} / \mathrm{gp} 42-\mathrm{NP}$ constructs show the $\mathrm{gH} / \mathrm{gL}$ or $\mathrm{gH} / \mathrm{gL} / \mathrm{gp} 42$ fused to $H$. pylori ferritin (represented by the letter "F" in beige) by a flexible amino acid linker (line), respectively. (B) Left: The crystal structure of the single chain $\mathrm{gH} / \mathrm{gL}$ was resolved at $5.5 \AA$ (gL in green and $\mathrm{gH}$ in cyan) with superposition of the previously solved crystal structure of $\mathrm{gH} / \mathrm{gL}$ complex (white, PDB: 3PHF) $(\mathrm{RMS}=0.33)$. Right: The crystal structure of the single chain $\mathrm{gH} / \mathrm{gL} / \mathrm{gp} 42$ was resolved at $2.9 \AA$ and superposition with the previously solved heterotrimer $\mathrm{gH} / \mathrm{gL} / \mathrm{gp} 42$ complex crystal structure (white, PDB: 5T1D) (RMS value =0.96). (C) Left: Size exclusion chromatography (SEC) elution profiles of single chain gH/gL-NP and single chain gH/gL/gp42-NP. Right: Size of single chain gH/gL-NP and single chain $\mathrm{gH} / \mathrm{gL} / \mathrm{gp} 42-\mathrm{NP}$ determined by DLS. (D) Negative stain EM image of single chain gH/gL-NP and single chain gH/gL/gp42-NP. A close-up image of the nanoparticle is displayed at the upper right corner. A structural model of the single chain $\mathrm{gH} / \mathrm{gL}-$ $\mathrm{NP}$ or single chain $\mathrm{gH} / \mathrm{gL} / \mathrm{gp} 42-\mathrm{NP}$ is shown on the right of the EM image (gH: cyan; gL: green; gp42: gray; ferritin: orange). The surface density is a model built from crystal structures solved in panel B and ferritin core from PDB 3BVE (DOI:10.2210/pdb3bve/pdb) using Chimera (40) and is 
Figure 2. Neutralization responses induced by single chain gH/gL-NP or single chain

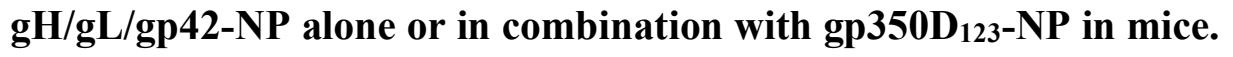

BALB/C mice ( $n=5 /$ group) were immunized intramuscularly in the presence of AF03 adjuvant at weeks 0 and 3 with $1 \mu \mathrm{g}$ of (A) monovalent single chain $\mathrm{gH} / \mathrm{gL}-\mathrm{NP}$, gp $350 \mathrm{D}_{123}$ or bivalent $\mathrm{gH} / \mathrm{gL}-\mathrm{NP}+\mathrm{gp} 350 \mathrm{D}_{123}-\mathrm{NP}$ or (B) monovalent single chain $\mathrm{gH} / \mathrm{gL} / \mathrm{gp} 42-\mathrm{NP}$ or bivalent $\mathrm{gH} / \mathrm{gL} / \mathrm{gp} 42-\mathrm{NP}+\mathrm{gp} 350 \mathrm{D}_{123}-\mathrm{NP}$. Control is pre-immune sera. Neutralization antibody titers from immune sera collected 2 weeks after the $2^{\text {nd }}$ injection was determined in Raji B cells and SVK CR2 epithelial cells. The $\mathrm{IC}_{50}$ indicated the $\log$ titer that resulted in $50 \%$ inhibition of EBV entry into target cells. The data are shown as box-and-whiskers plots (box indicates lower and upper quartiles with line at median, and whiskers span minimum and maximum data points; ${ }^{*} \mathrm{p}<0.05$ compared to control).

Figure 3. Immunogenicity of single chain gH/gL-NP+gp350D $123-\mathrm{NP}$ or single chain gH/gL/gp42-NP alone or in combination with gp350D $123-\mathrm{NP}$ in ferrets and NHP.

(A) Ferrets were immunized intramuscularly at weeks 0 and 4 with either $15 \mu \mathrm{g}$ single

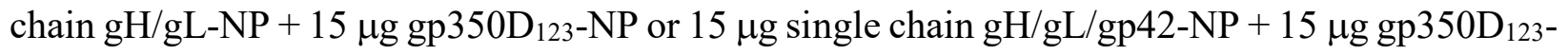
NP bivalent vaccines. Sera were collected 2 weeks after immunization and were assayed for neutralizing activity in both Raji B cells (left) and 293 epithelial cells (right). Means and standard deviations are shown $(* \mathrm{p}<0.05$ compared to pre-immune sera). No neutralizing activity was detected from the pre-immune sera and levels were at the limit of detection in the graphs. Rhesus macaques ( $\mathrm{n}=4$ /group) were vaccinated with the bivalent vaccine composed of $25 \mu \mathrm{g}$ $\mathrm{gH} / \mathrm{gL}-\mathrm{NP}+25 \mu \mathrm{g}$ gp350D ${ }_{123}-\mathrm{NP}$ or $25 \mu \mathrm{g} \mathrm{gH} / \mathrm{gL} / \mathrm{gp} 42-\mathrm{NP}+25 \mu \mathrm{g}$ gp350D ${ }_{123}-\mathrm{NP}$ at weeks 0,4 , and 10. AF03 was used as adjuvant. Immune sera were collected 2 weeks after the $3^{\text {rd }}$ injection 
and neutralizing antibody titers were determined in both Raji B cells and SVK CR2 epithelial cells. Means and standard deviations are shown $(* \mathrm{p}<0.05$ compared to pre-immune sera).

Figure 4. Immune protection by passive transfer of bivalent vaccine sera against EBV infection in humanized NSG mice.

Humanized NSG mice (n=6/group) were injected IgG $(20 \mu \mathrm{g} / \mathrm{g}$ of mouse body weight) purified from naïve (control), single chain $\mathrm{gH} / \mathrm{gL}-\mathrm{NP}+\mathrm{gp} 350 \mathrm{D}_{123}-\mathrm{NP}$ or single chain $\mathrm{gH} / \mathrm{gL} / \mathrm{gp} 42+\mathrm{gp} 350 \mathrm{D}_{123}-\mathrm{NP}$ immunized BALB/C mice. Passive transfer of IgG was delivered intraperitoneally on day $-1,0$ and 1 and EBV challenge was performed intravenously on day 0. (A) Viremia from each group was measured at weeks 5 7, and 9 post challenge. Medians with 25\% and $75 \%$ percentiles are shown $(* \mathrm{p}<0.05$ compared to control at the same week). (B) Heatmap showing EBV encoded RNA 1 (EBER1) positivity of tissues (graded 0 to 3 ) from mice receiving IgG from naïve, single chain $\mathrm{gH} / \mathrm{gL}-\mathrm{NP}+\mathrm{gp} 350 \mathrm{D}_{123}-\mathrm{NP}$, or single chain $\mathrm{gH} / \mathrm{gL} / \mathrm{gp} 42+{\mathrm{gp} 350 \mathrm{D}_{123}-}^{-}$ NP immunized BALB/C mice after challenge with EBV. A score of 0 indicates no EBER1 staining while a score of 3 indicates marked infiltration of tissues by EBER1-positive cells.

\section{Figure 5. Protection against EBV lymphoma in vivo.}

Pathologic and immunohistochemical analysis of the liver from representative mice receiving IgG from non-immune (Control, left) or vaccinated mice (Immune, middle and right) after challenge with EBV. Tissues were collected 27 weeks after challenge and stained with hematoxylin and eosin (H\&E, yellow arrows indicate representative region with lymphoma) or anti-CD20 antibody (brown staining, red arrows), or in situ hybridization was performed with a probe to EBER1 (purple staining, red arrows). CD20 and EBER staining are apparent in control, 
bioRxiv preprint doi: https://doi.org/10.1101/2022.01.18.476774; this version posted January 20, 2022. The copyright holder for this preprint (which was not certified by peer review) is the author/funder. All rights reserved. No reuse allowed without permission.

472 but not in any of the tissues receiving IgG from vaccinated mice. No EBV-positive B cell

473 lymphomas were observed in the latter animals.

474 


\section{Table S1. Data collection and refinement statistics (molecular replacement)}

\begin{tabular}{|c|c|c|}
\hline & Single chain gH/gL/gp42 & Single chain $\mathrm{gH} / \mathrm{gL} /$ \\
\hline \multicolumn{3}{|l|}{ Data collection } \\
\hline Space group & P 212121 & $\mathrm{C} 2$ \\
\hline \multicolumn{3}{|l|}{ Cell dimensions } \\
\hline$a, b, c(\AA)$ & $89.85,120.94,143.65$ & $543.4,167.4,383.6$ \\
\hline$\alpha, \beta, \gamma\left({ }^{\circ}\right)$ & 909090 & 9013490 \\
\hline Resolution $(\AA)$ & $89.85-2.87(2.94-2.87)$ & $195-5.5(5.52-5.5)$ \\
\hline$R_{\text {merge }}$ & $0.148(2.024)$ & $0.095(1.26)$ \\
\hline$R_{\text {meas }}$ & $0.161(2.202)$ & $0.116(1.42)$ \\
\hline$I / \sigma I$ & $9.2(1.0)$ & $8.2(1.0)$ \\
\hline$C C_{1 / 2}$ & $0.997(0.401)$ & $0.992(0.329)$ \\
\hline Completeness (\%) & $99.9(100.0)$ & $97.9(92.7)$ \\
\hline Redundancy & $6.4(6.5)$ & $3.9(3.4)$ \\
\hline \multicolumn{3}{|l|}{ Refinement } \\
\hline Resolution $(\AA)$ & $61.76-2.87(2.973-2.87)$ & $136.2-5.5(5.64-5.5)$ \\
\hline No. reflections & $36423(3580)$ & $76750(5476)$ \\
\hline$R_{\text {work }} / R_{\text {free }}$ & $\begin{array}{c}0.2241 / 0.2520(0.3500 / \\
0.4206)\end{array}$ & $0.299 / 0.338(0.38 / 0.395)$ \\
\hline No. atoms & 7437 & 85882 \\
\hline Protein & 7293 & 85882 \\
\hline Ligand/ion & 144 & 0 \\
\hline Water & 0 & 0 \\
\hline$B$-factor & 85.83 & 279.3 \\
\hline Protein & 84.86 & 279.3 \\
\hline Ligand/ion & 119.27 & N/A \\
\hline \multicolumn{3}{|l|}{ Ramachandran } \\
\hline Favored (\%) & 96.62 & 92.9 \\
\hline Allowed (\%) & 3.38 & 6.72 \\
\hline Outlier (\%) & 0.00 & 0.28 \\
\hline \multicolumn{3}{|l|}{ R.m.s. deviations } \\
\hline Bond lengths $(\AA)$ & 0.002 & 0.002 \\
\hline Bond angles $\left({ }^{\circ}\right)$ & 0.48 & 1.220 \\
\hline \multicolumn{3}{|l|}{ Molprobity } \\
\hline Clashscore & 2.78 & 10.79 \\
\hline Rotamer outliers (\%) & 0.99 & 2.2 \\
\hline $\mathrm{C} \beta$ deviations & 0 & 0.03 \\
\hline Cis-proline (\%) & 0.00 & 0.00 \\
\hline Twisted proline (\%) & 0.00 & 0.21 \\
\hline
\end{tabular}


Table S2. Amino acid sequences of constructs used

\begin{tabular}{|c|c|}
\hline Construct & 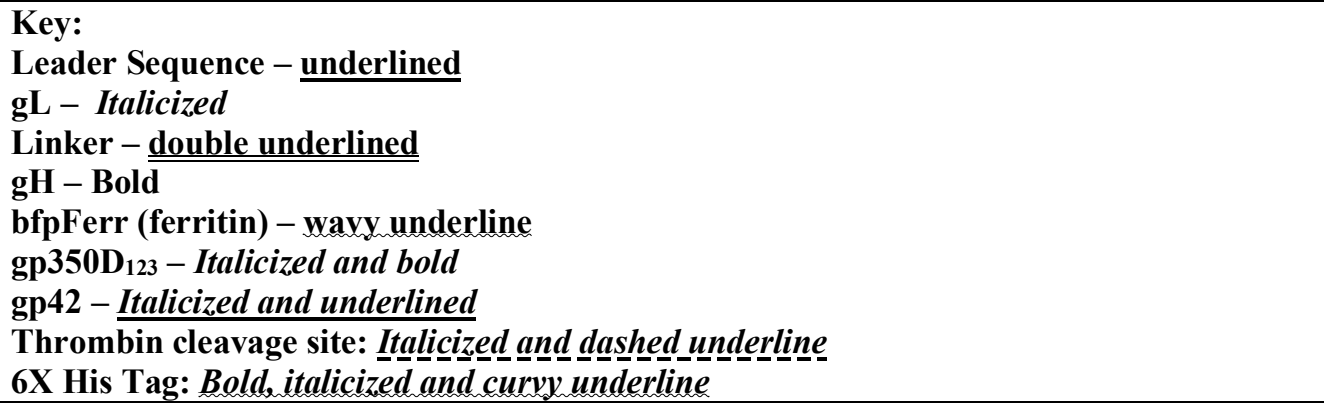 \\
\hline $\begin{array}{l}\text { gp350D }_{123} \\
\text { monomer }\end{array}$ & $\begin{array}{l}\text { MDSKGSSQKGSRLLLLLVVSNLLLPQGVLAEAALLVCQYTIQSLIHLTGEDPGFFNV } \\
\text { EIPEFPFYPTCNVCTADVNVTINFDVGGKKHQLDLDFGQLTPHTKAVYQPRGAFGGS } \\
\text { ENATNLFLLELLGAGELALTMRSKLLINVTTGEEQQVSLESVDVYFQDVFGTMWC } \\
\text { HHAEMQNPVYLIPETVPYIKWDNCNSTNITAVVRAQGLDVTLPLSLPTSAQDSNFSV } \\
\text { KTEMLGNEIDIECIMEDGEISQVLPGDNFNITCSGYESHVPSGGILTSTSPVATPIPG } \\
\text { TGYAYSLRLTPRPVSRFGNNSILYVFYSGNGPKASGGDYCIQSNIVSDEIPASQDMP } \\
\text { TNTTDITYVGDNATYSVPMVTSEDANSPNVTVTAFWAWPNNTETDFKCKWTLTSGT } \\
\text { PSGCENISGAFASNRTFDITVSGLGTAPKTLIITRTATNATTTTHKVIFSKAPEGSGSGS } \\
\text { GLVPRGSGAGGGHHHHH }\end{array}$ \\
\hline $\begin{array}{l}\mathrm{gH} / \mathrm{gL} \\
\text { monomer }\end{array}$ & 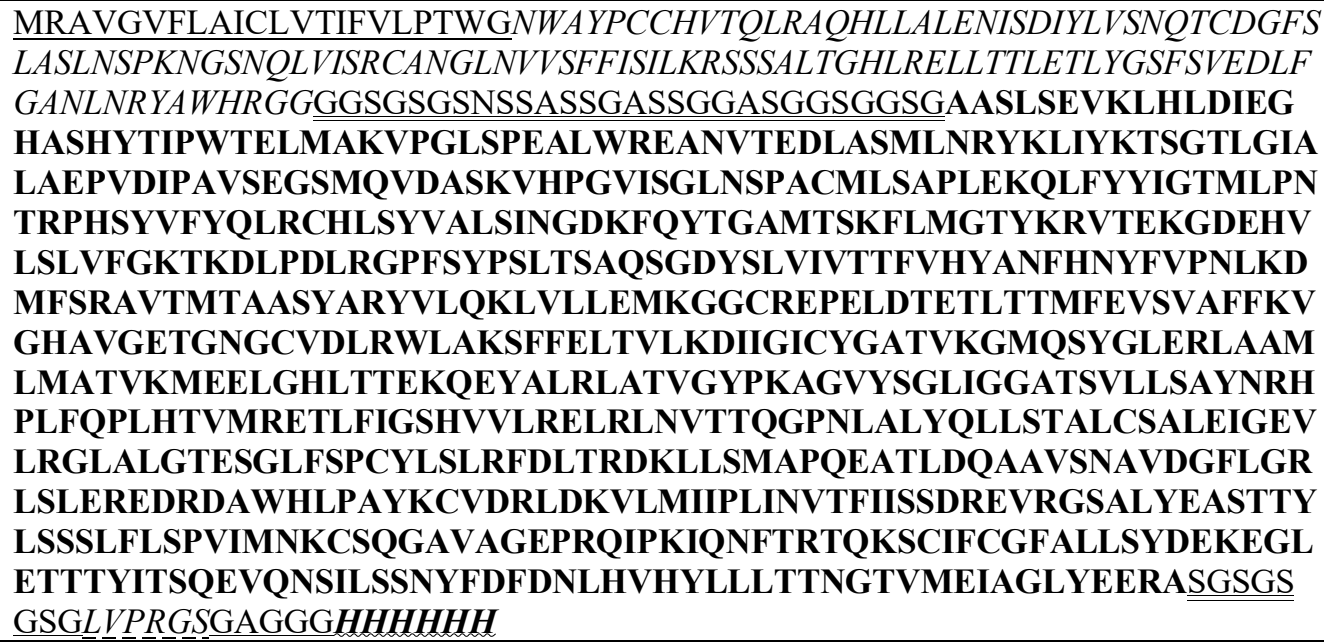 \\
\hline $\begin{array}{c}\mathrm{gL} / \mathrm{gH} / \mathrm{gp} 42 \\
\text { monomer }\end{array}$ & 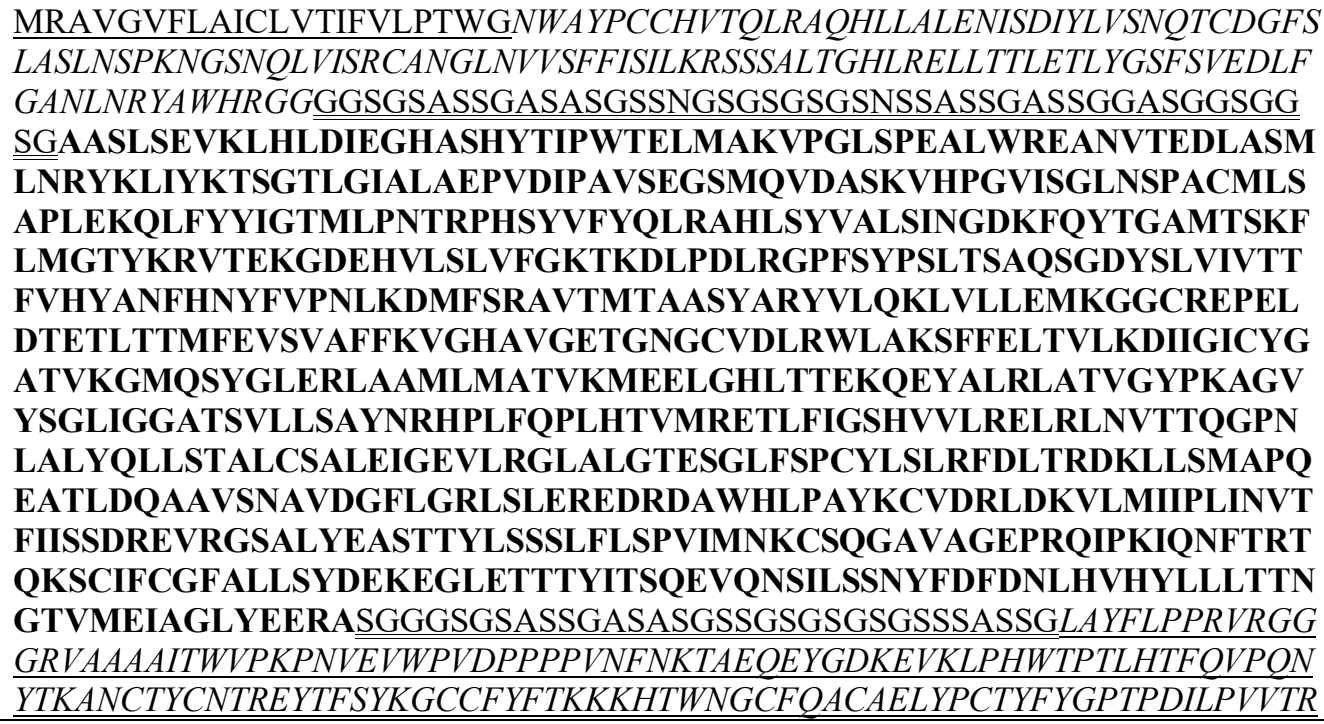 \\
\hline
\end{tabular}




\begin{tabular}{|c|c|}
\hline & $\begin{array}{l}\text { NLNAIESLWVGVYRVGEGNWTSLDGGTFKVYQIFGSHCTYVSKFSTVPVSHHECSFLKPCL } \\
\text { CVSQRSNSGSHHHHHH }\end{array}$ \\
\hline $\begin{array}{l}\mathrm{gp} 350 \mathrm{D}_{123} \\
\text { nanoparticle }\end{array}$ & $\begin{array}{l}\text { MDSKGSSQKGSRLLLLLVVSNLLLPQGVLAEAALLVCQYTIQSLIHLTGEDPGFFNV } \\
\text { EIPEFPFYPTCNVCTADVNVTINFDVGGKKHQLDLDFGQLTPHTKAVYQPRGAFGGS } \\
\text { ENATNLFLLELLGAGELALTMRSKKLPINTTGEEQQVSLESVDVYFQDVFGTMWC } \\
\text { HHAEMQNPVYLIPETVPYIKWDNCNSTNITAVVRQGLDVTLPLSLPTSAQDSNFSV } \\
\text { KTEMLGNEIDIECIMEDGEISQVLPGDNKFNITSGYESHVPSGILTSTSPVATPIPG } \\
\text { TGYAYSLRLTPRPVSRFLGNNSILYVFYSGNGPKASGGDYCIQSNIVFSDEIPASQDMP } \\
\text { TNTTDITYVGDNATYSVPMVTSEDANSPNVTVTAFWAWPNNTETDFKCKWTLTSGT } \\
\text { PSGCENISGAFASNRTFDITVSGLGTAPKTLITRTATNATTTTHKVIFSKAPEGSESQV } \\
\text { RQQFSKDIEKLLNEQVNKEMQSSNLYMSMSSWSYTHSLDGAGLFLFDHAAEEYEHA } \\
\text { KKLIIFLNENNVPVQLTSISAPEHKFEGLTQIFQKAYEHEQHISESINNIVDHAIKCKDH } \\
\text { ATFNFLQWYVAEQHEEEVLFKDILDKIELIGNENHGLYLADQYVKGIAKSRKS }\end{array}$ \\
\hline $\begin{array}{c}\mathrm{gH} / \mathrm{gL} \\
\text { nanoparticle }\end{array}$ & 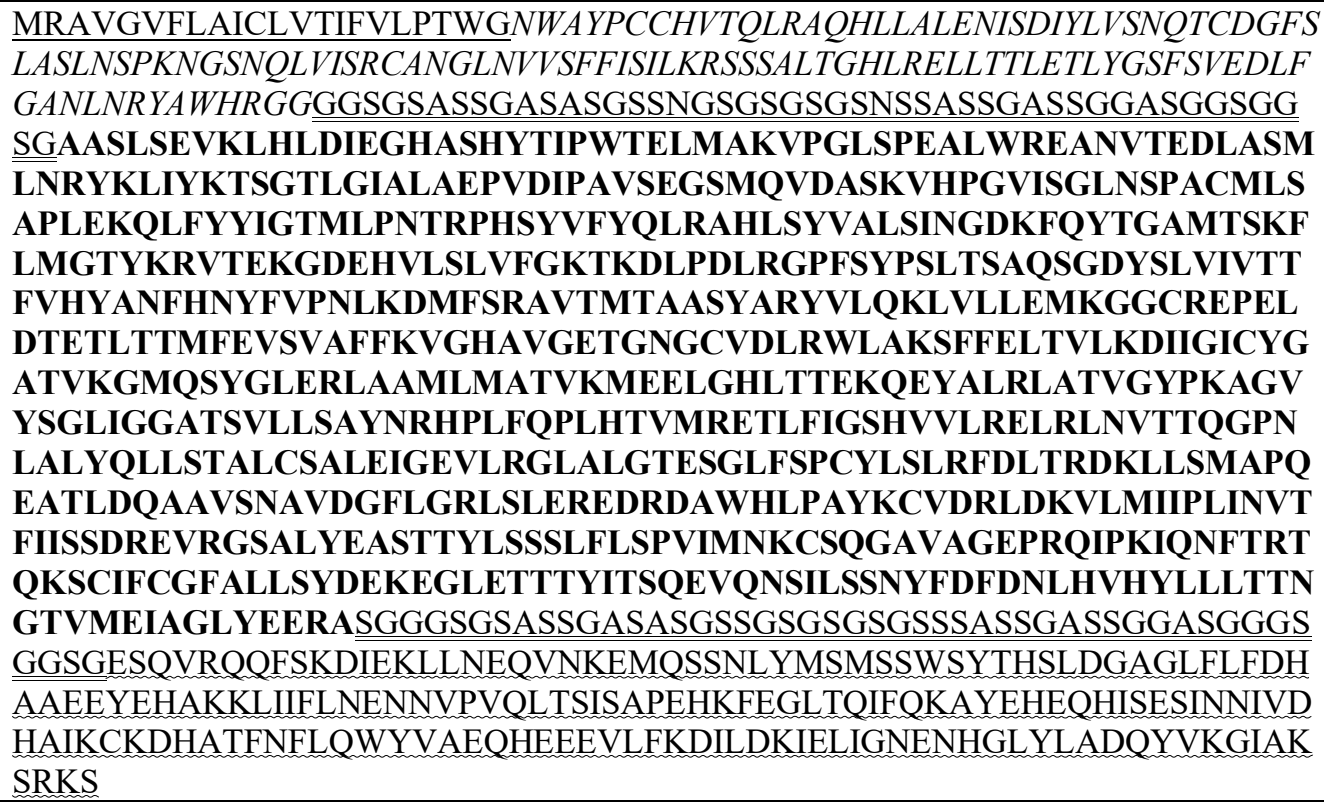 \\
\hline & 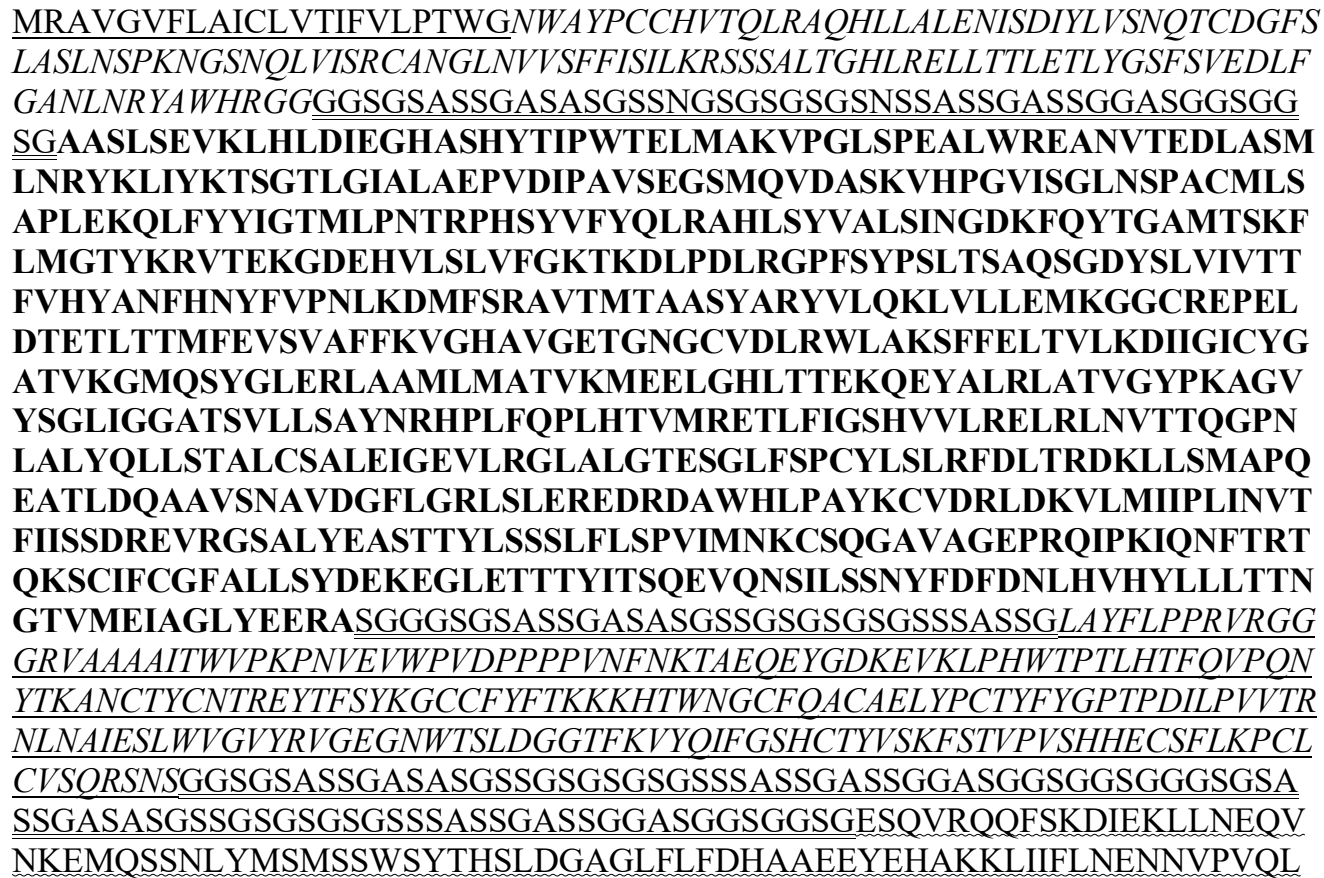 \\
\hline
\end{tabular}


bioRxiv preprint doi: https://doi.org/10.1101/2022.01.18.476774; this version posted January 20, 2022. The copyright holder for this preprint (which was not certified by peer review) is the author/funder. All rights reserved. No reuse allowed without permission.

488

TSISAPEHKFEGLTQIFQKAYEHEQHISESINNIVDHAIKCKDHATFNFLQWYVAEQHE EEVLFKDILDKIELIGNENHGLYLADQYVKGIAKSRKS 

to pre-immune sera). constructs. adjuvant. mice.

\section{SUPPLEMENTAL FIGURES}

Supplemental Figure 1. Expression of single chain $\mathrm{gH} / \mathrm{gL}$ and single chain $\mathrm{gH} / \mathrm{gL} / \mathrm{gp42}$

\section{Supplemental Figure 2. Immunogenicity of single chain gH/gL-NP with or without AF03}

Mice were immunized at week 0 and week 3 . Immune sera were collected at weeks 0,2 and 5 and antibody titers were determined by ELISA. Mean and standard error are shown. The $p$ value from week 5 was $<0.0001$.

\section{Supplemental Figure 3. Immunogenicity of single chain $\mathrm{gH} / \mathrm{gL}-\mathrm{NP}$ and gp350D $_{123}-\mathrm{NP}$ in}

A monovalent single chain $\mathrm{gH} / \mathrm{gL}-\mathrm{NP}$ or gp350D ${ }_{123}-\mathrm{NP}$, or bivalent single chain $\mathrm{gH} / \mathrm{gL}-$ $\mathrm{NP}+\mathrm{gp} 350 \mathrm{D}_{123}-\mathrm{NP}$ was used to immunize mice with AF03 as adjuvant. Antibody titers pre- and post-immunization against either (a) $\mathrm{gH} / \mathrm{gL}$ heterodimer or (b) gp350D 123 were determined by ELISA. The data are shown as box-and-whiskers plots (box indicates lower and upper quartiles with line at median, and whiskers span minimum and maximum data points; ${ }^{*} \mathrm{p}<0.0001$ compared 

in mice.

Monovalent single chain gH/gLgp42-NP (a) or bivalent single chain gH/gL-NP/gp42-

$517 \mathrm{NP}+\mathrm{gp} 350 \mathrm{D}_{123}-\mathrm{NP}$ (b) was used to immunize mice with AF03 as adjuvant. Antibody titers from

518 immune sera collected 2 weeks after first and second immunizations against either $\mathrm{gH} / \mathrm{gL}$

519 heterodimer, gp42 or gp350D 123 were determined by ELISA. The data are shown as box-and-

520 whiskers plots (box indicates lower and upper quartiles with line at median, and whiskers span

521 minimum and maximum data points; ${ }^{*} \mathrm{p}<0.0001$ compared to week 2 sera).

522

Supplemental Figure 5. Immunogenicity of single chain $\mathrm{gH} / \mathrm{gL}-\mathrm{NP}+\mathrm{gp350D}_{123}-\mathrm{NP}$ and single chain $\mathrm{gH} / \mathrm{gL} / \mathrm{gp} 42-\mathrm{NP}+\mathrm{gp} 350 \mathrm{D}_{123}-\mathrm{NP}$ vaccines in ferrets. $(* * p<0.0001$ or $* \mathrm{p}<0.05$ respectively compared to pre-immune sera). single chain $\mathrm{gH} / \mathrm{gL} / \mathrm{gp} 42-\mathrm{NP}+\mathrm{gp350D}_{123}-\mathrm{NP}$ vaccines in nonhuman primates. or (b) single chain $\mathrm{gH} / \mathrm{gL} / \mathrm{gp} 42-\mathrm{NP}+\mathrm{gp} 350 \mathrm{D}_{123}-\mathrm{NP}$ bivalent vaccines at weeks 0,4 , and 10 . Pre- 
537 Supplemental Figure 7. EBV lymphoma in challenged humanized mice. EBV-positive B cell

538 lymphomas and CD20 and EBER positive cells were observed in the (a) spleen and (b) kidney of 539 mice receiving IgG from naïve BALB/C after EBV challenge (Control). No evidence of EBV540 positive B cell lymphomas was seen in mice receiving IgG from animals vaccinated with single 541 chain $\mathrm{gH} / \mathrm{gL}-\mathrm{NP}+\mathrm{gp} 35 \mathrm{DD}_{123}-\mathrm{NP}$ or $\mathrm{gH} / \mathrm{gL} / \mathrm{gp} 42-\mathrm{NP}+\mathrm{gp} 350 \mathrm{D}_{123}-\mathrm{NP}$ (Immune). CD20 staining 542 and EBER are also negative in these mice. Tissues were harvested and stained as in Fig. 5. Arrows 543 indicate representative areas of pathology and staining for the indicated cellular or viral proteins.

\section{Supplemental Figure 8. Anti-gH, gL, and gp42 antibody levels in mice challenged with}

546 EBV. Antibody titers in plasma samples of humanized mice receiving IgG from vaccinated or

547 naïve (control) mice obtained one week after challenge were measured by LIPS assay and shown 548 as RLUs. Antibody titers in animals that received IgG from naïve, single chain $\mathrm{gH} / \mathrm{gL}-$

$549 \mathrm{NP}+\mathrm{gp} 350 \mathrm{D} 123-\mathrm{NP}$, and gH/gL/gp42-NP+gp350D123-NP immunized BALB/c mice are shown.

550 Each symbol indicates one mouse. Minimum and maximum data points are represented by

551 whiskers and box represents upper and lower quartiles with the horizontal line at the median. 


\section{REFERENCES}

556 1. J. I. Cohen, E. S. Mocarski, N. Raab-Traub, L. Corey, G. J. Nabel, The need and

$557 \quad$ challenges for development of an Epstein-Barr virus vaccine. Vaccine 31 Suppl 2, B194-

$558 \quad 196(2013)$.

559 2. J. I. Cohen, A. S. Fauci, H. Varmus, G. J. Nabel, Epstein-Barr virus: an important vaccine

$560 \quad$ target for cancer prevention. Sci Transl Med 3, 107fs107 (2011).

561 3. D. Dierickx, T. M. Habermann, Post-Transplantation Lymphoproliferative Disorders in

562

563

564 Adults. N Engl J Med 378, 549-562 (2018).

4. J. I. Cohen, Epstein-barr virus vaccines. Clin Transl Immunology 4, e32 (2015).

5. J. D. Fingeroth et al., Epstein-Barr virus receptor of human B lymphocytes is the C3d receptor CR2. Proc Natl Acad Sci U S A 81, 4510-4514 (1984).

565

566

6. M. K. Spriggs et al., The extracellular domain of the Epstein-Barr virus BZLF2 protein

567

568 binds the HLA-DR beta chain and inhibits antigen presentation. $J$ Virol 70, 5557-5563 (1996).

7. J. I. Cohen, Vaccine Development for Epstein-Barr Virus. Adv Exp Med Biol 1045, 477493 (2018).

571

572

573

574

575

576

577

578

8. J. Chen et al., Ephrin receptor A2 is a functional entry receptor for Epstein-Barr virus. Nat Microbiol 3, 172-180 (2018).

9. H. Zhang et al., Ephrin receptor A2 is an epithelial cell receptor for Epstein-Barr virus entry. Nat Microbiol 3, 1-8 (2018).

10. E. M. Sokal et al., Recombinant gp350 vaccine for infectious mononucleosis: a phase 2, randomized, double-blind, placebo-controlled trial to evaluate the safety, immunogenicity, and efficacy of an Epstein-Barr virus vaccine in healthy young adults. $J$ Infect Dis 196, 1749-1753 (2007).

11. M. A. Epstein, A. J. Morgan, S. Finerty, B. J. Randle, J. K. Kirkwood, Protection of cottontop tamarins against Epstein-Barr virus-induced malignant lymphoma by a prototype subunit vaccine. Nature 318, 287-289 (1985).

12. J. Sashihara et al., Soluble rhesus lymphocryptovirus gp 350 protects against infection and reduces viral loads in animals that become infected with virus after challenge. PLoS Pathog 7, e1002308 (2011).

13. X. Cui et al., Rabbits immunized with Epstein-Barr virus gH/gL or gB recombinant proteins elicit higher serum virus neutralizing activity than gp350. Vaccine 34, 40504055 (2016).

14. M. Kanekiyo et al., Rational Design of an Epstein-Barr Virus Vaccine Targeting the Receptor-Binding Site. Cell 162, 1090-1100 (2015).

15. W. Bu et al., Immunization with Components of the Viral Fusion Apparatus Elicits Antibodies That Neutralize Epstein-Barr Virus in B Cells and Epithelial Cells. Immunity 50, 1305-1316 e1306 (2019).

16. T. Vesikari, S. Pepin, I. Kusters, A. Hoffenbach, M. Denis, Assessment of squalene adjuvanted and non-adjuvanted vaccines against pandemic H1N1 influenza in children 6 months to 17 years of age. Hum Vaccin Immunother 8, 1283-1292 (2012).

17. A. Carville, K. G. Mansfield, Comparative pathobiology of macaque lymphocryptoviruses. Comp Med 58, 57-67 (2008).

18. S. Fujiwara, K. Imadome, M. Takei, Modeling EBV infection and pathogenesis in newgeneration humanized mice. Exp Mol Med 47, e135 (2015). 
600 19. S. Fujiwara, G. Matsuda, K. Imadome, Humanized mouse models of epstein-barr virus infection and associated diseases. Pathogens 2, 153-176 (2013).

602

603

604

605

606

607

608

609

20. M. Islas-Ohlmayer et al., Experimental infection of NOD/SCID mice reconstituted with human CD34+ cells with Epstein-Barr virus. J Virol 78, 13891-13900 (2004).

21. M. Yajima et al., A new humanized mouse model of Epstein-Barr virus infection that reproduces persistent infection, lymphoproliferative disorder, and cell-mediated and humoral immune responses. J Infect Dis 198, 673-682 (2008).

22. G. M. Escalante et al., A Pentavalent Epstein-Barr Virus-Like Particle Vaccine Elicits High Titers of Neutralizing Antibodies against Epstein-Barr Virus Infection in Immunized Rabbits. Vaccines (Basel) 8, (2020).

23. C. Cox et al., Immunization of common marmosets with Epstein-Barr virus (EBV) envelope glycoprotein gp340: effect on viral shedding following EBV challenge. $J$ Med Virol 55, 255-261 (1998).

24. G. Khan, W. Ahmed, P. S. Philip, M. H. Ali, A. Adem, Healthy rabbits are susceptible to Epstein-Barr virus infection and infected cells proliferate in immunosuppressed animals. Virol J 12, 28 (2015).

25. D. Espinosa et al., Passive Transfer of Immune Sera Induced by a Zika Virus-Like Particle Vaccine Protects AG129 Mice Against Lethal Zika Virus Challenge. EBioMedicine 27, 61-70 (2018).

26. M. K. Howard et al., H5N1 whole-virus vaccine induces neutralizing antibodies in humans which are protective in a mouse passive transfer model. PLoS One 6, e23791 (2011).

27. T. F. Rogers et al., Isolation of potent SARS-CoV-2 neutralizing antibodies and protection from disease in a small animal model. Science 369, 956-963 (2020).

28. C. Munz, Immune Control and Vaccination against the Epstein-Barr Virus in Humanized Mice. Vaccines (Basel) 7, (2019).

29. W. Kabsch, Integration, scaling, space-group assignment and post-refinement. Acta Crystallogr D Biol Crystallogr 66, 133-144 (2010).

30. W. Kabsch, Xds. Acta Crystallogr D Biol Crystallogr 66, 125-132 (2010).

31. A. J. McCoy, Solving structures of protein complexes by molecular replacement with Phaser. Acta Crystallogr D Biol Crystallogr 63, 32-41 (2007).

32. A. J. McCoy et al., Phaser crystallographic software. J Appl Crystallogr 40, 658-674 (2007).

33. P. Emsley, B. Lohkamp, W. G. Scott, K. Cowtan, Features and development of Coot. Acta Crystallogr D Biol Crystallogr 66, 486-501 (2010).

34. P. D. Adams et al., PHENIX: a comprehensive Python-based system for macromolecular structure solution. Acta Crystallogr D Biol Crystallogr 66, 213-221 (2010).

35. A. E. Coghill et al., High Levels of Antibody that Neutralize B-cell Infection of EpsteinBarr Virus and that Bind EBV gp350 Are Associated with a Lower Risk of Nasopharyngeal Carcinoma. Clin Cancer Res 22, 3451-3457 (2016).

36. J. Sashihara, P. D. Burbelo, B. Savoldo, T. C. Pierson, J. I. Cohen, Human antibody titers to Epstein-Barr Virus (EBV) gp350 correlate with neutralization of infectivity better than antibody titers to EBV gp42 using a rapid flow cytometry-based EBV neutralization assay. Virology 391, 249-256 (2009). 
644 37. M. Gupta, S. Mahanty, M. Bray, R. Ahmed, P. E. Rollin, Passive transfer of antibodies

645

646

647

648

649

650

651

652

653

654

655

656

657

658

659

660

661

662

663 protects immunocompetent and imunodeficient mice against lethal Ebola virus infection without complete inhibition of viral replication. J Virol 75, 4649-4654 (2001).

38. J. Maamary, T. T. Wang, G. S. Tan, P. Palese, J. V. Ravetch, Increasing the breadth and potency of response to the seasonal influenza virus vaccine by immune complex immunization. Proc Natl Acad Sci U S A 114, 10172-10177 (2017).

39. T. Strowig et al., Priming of protective T cell responses against virus-induced tumors in mice with human immune system components. J Exp Med 206, 1423-1434 (2009).

40. E. F. Pettersen et al., UCSF Chimera--a visualization system for exploratory research and analysis. J Comput Chem 25, 1605-1612 (2004). 


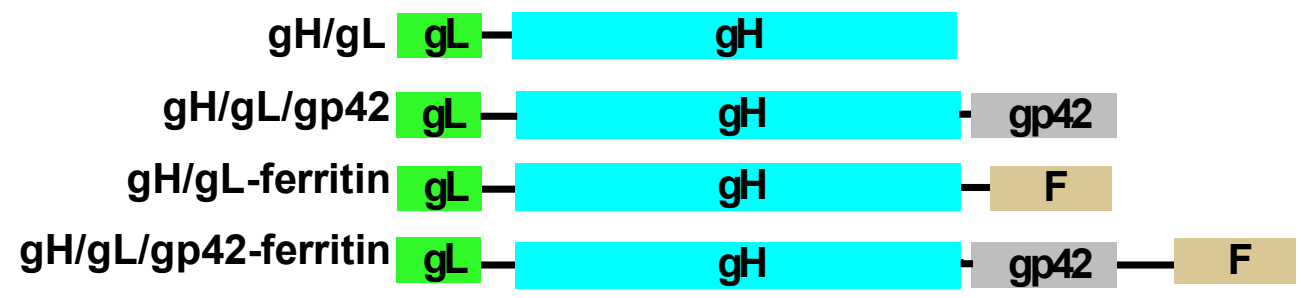

B

gH/gL

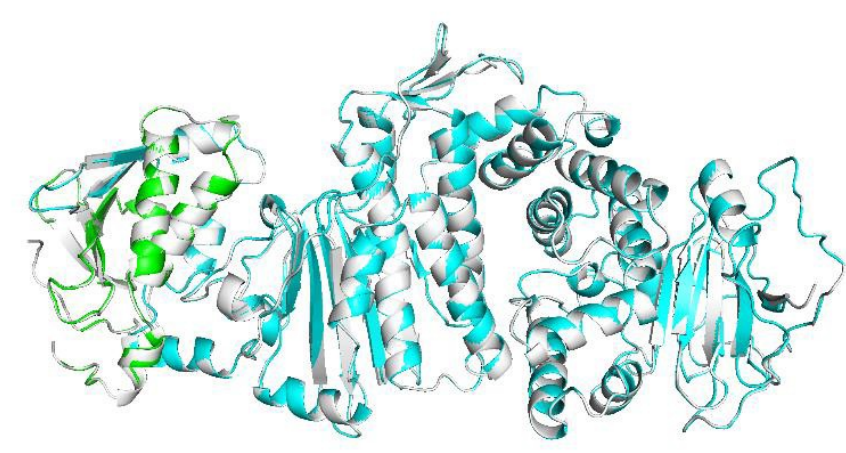

C

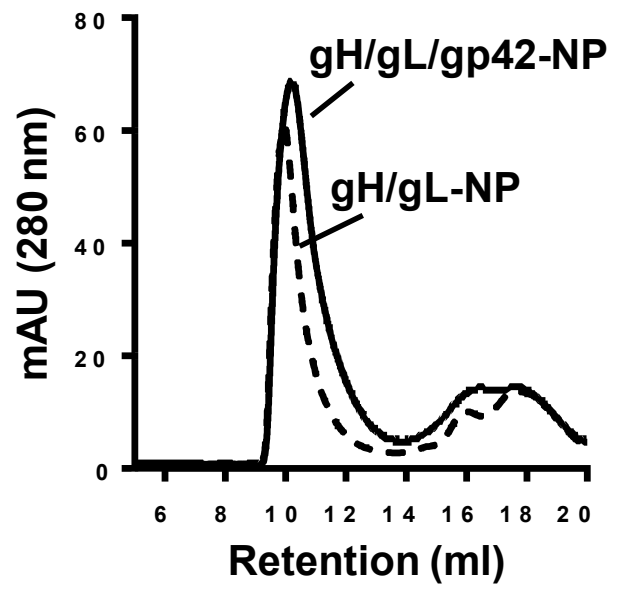

gH/gL/gp42

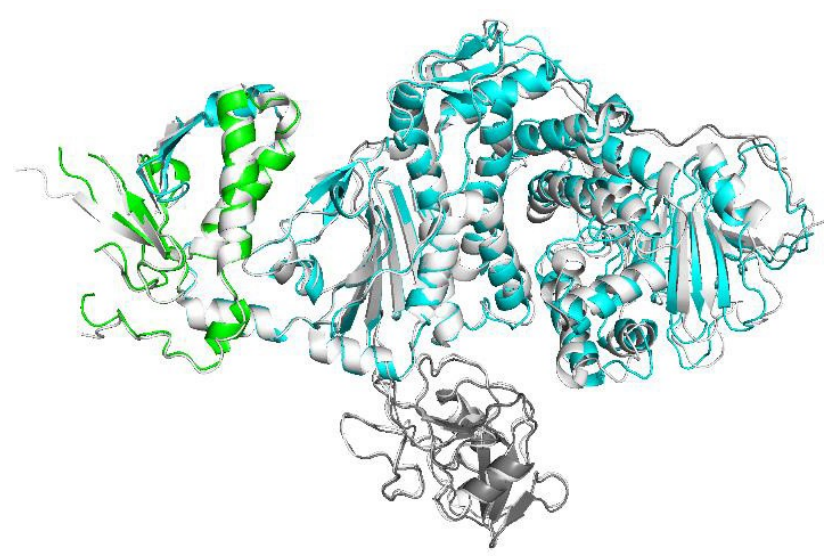

gH/gL-NP gH/gL/gp42-NP

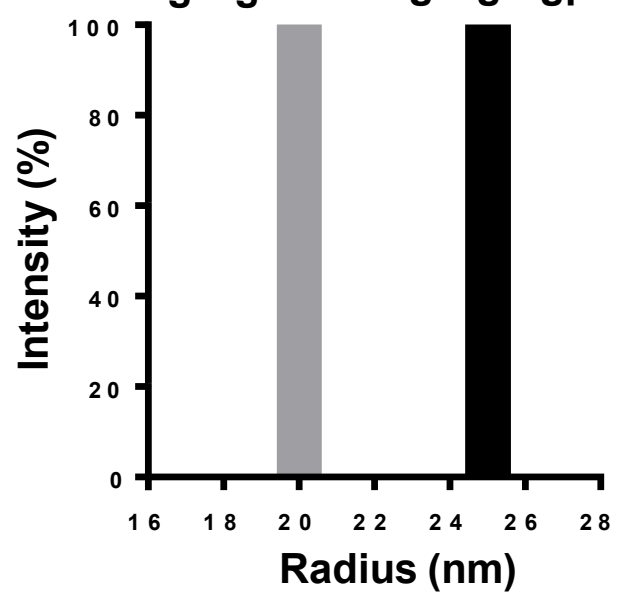

D

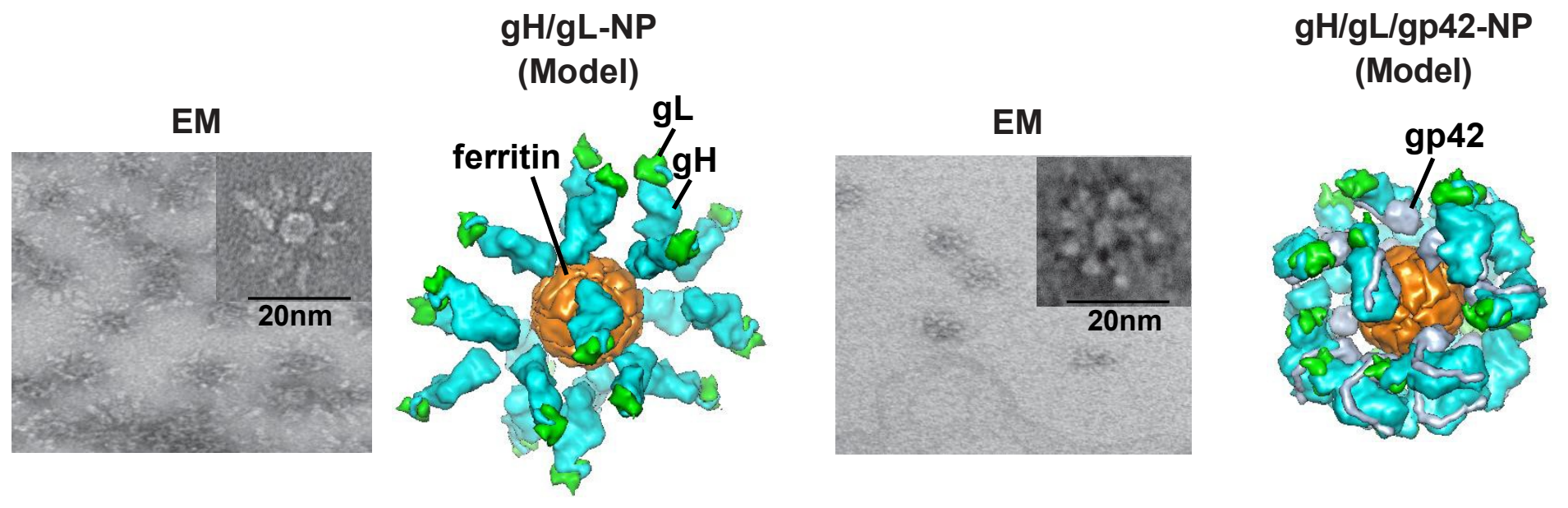


A

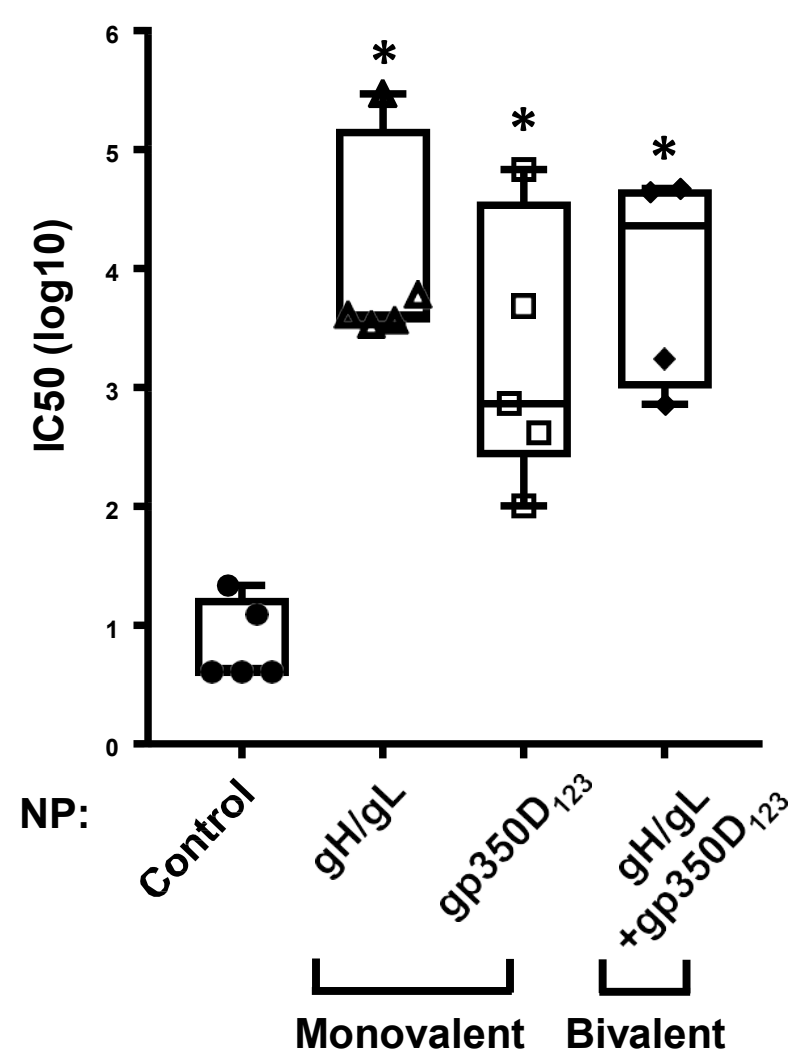

NP:

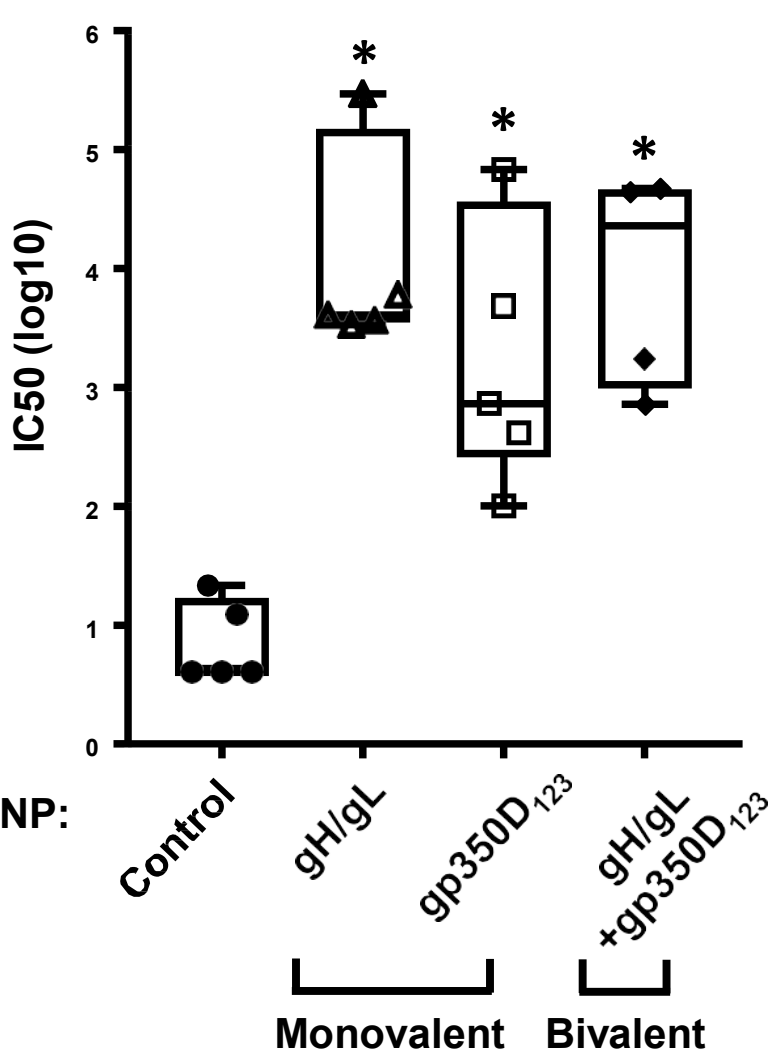

B

\section{B cell}

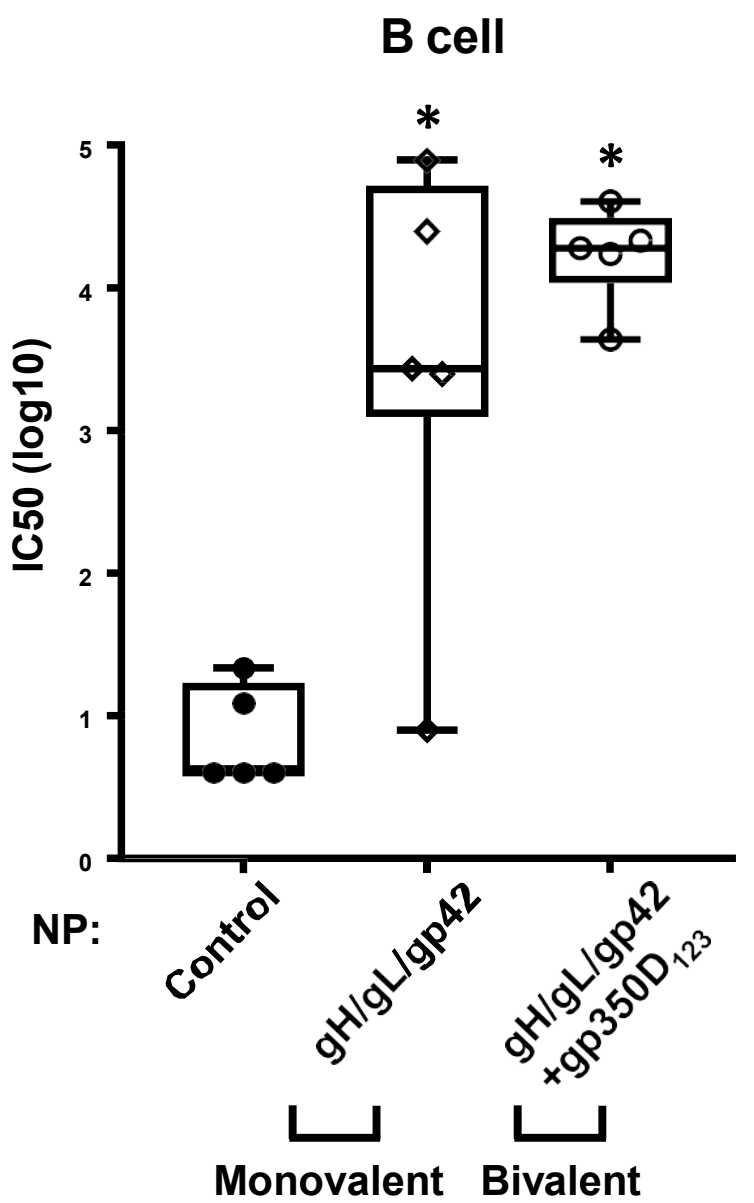

Epithelial cell

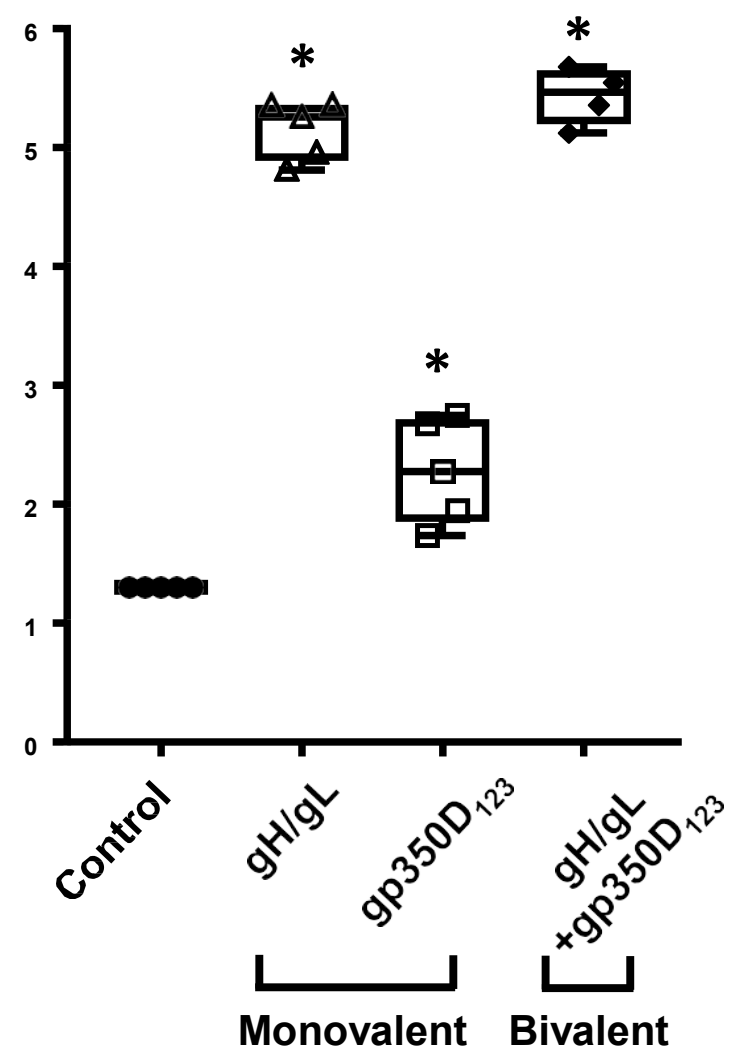

Epithelial cell

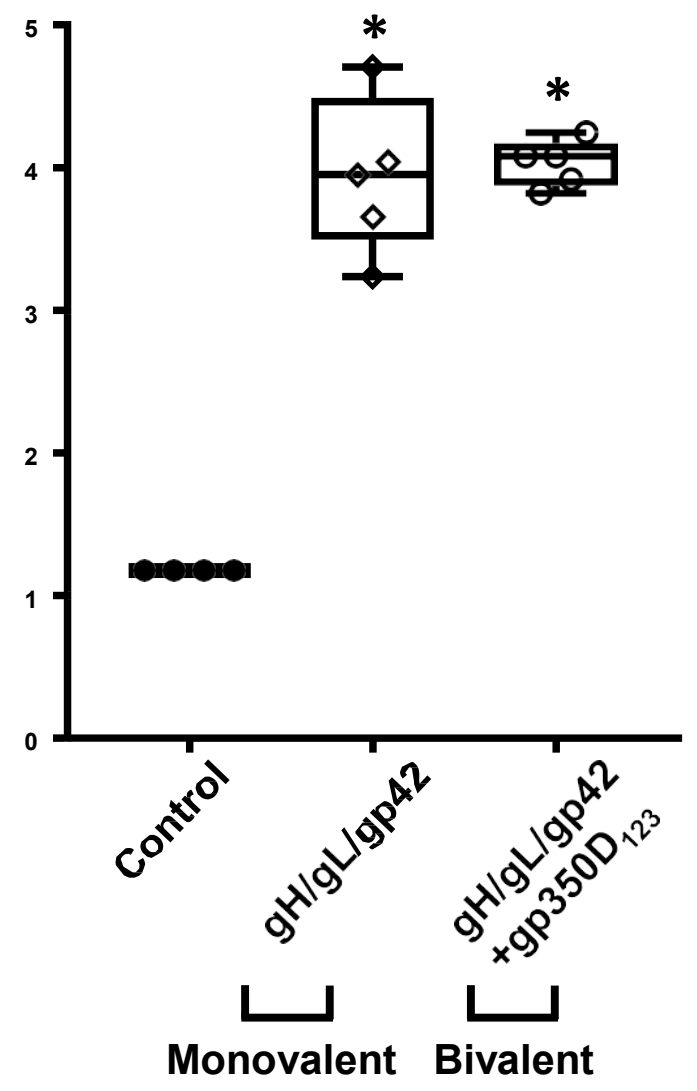




\section{Ferret (naïve)}
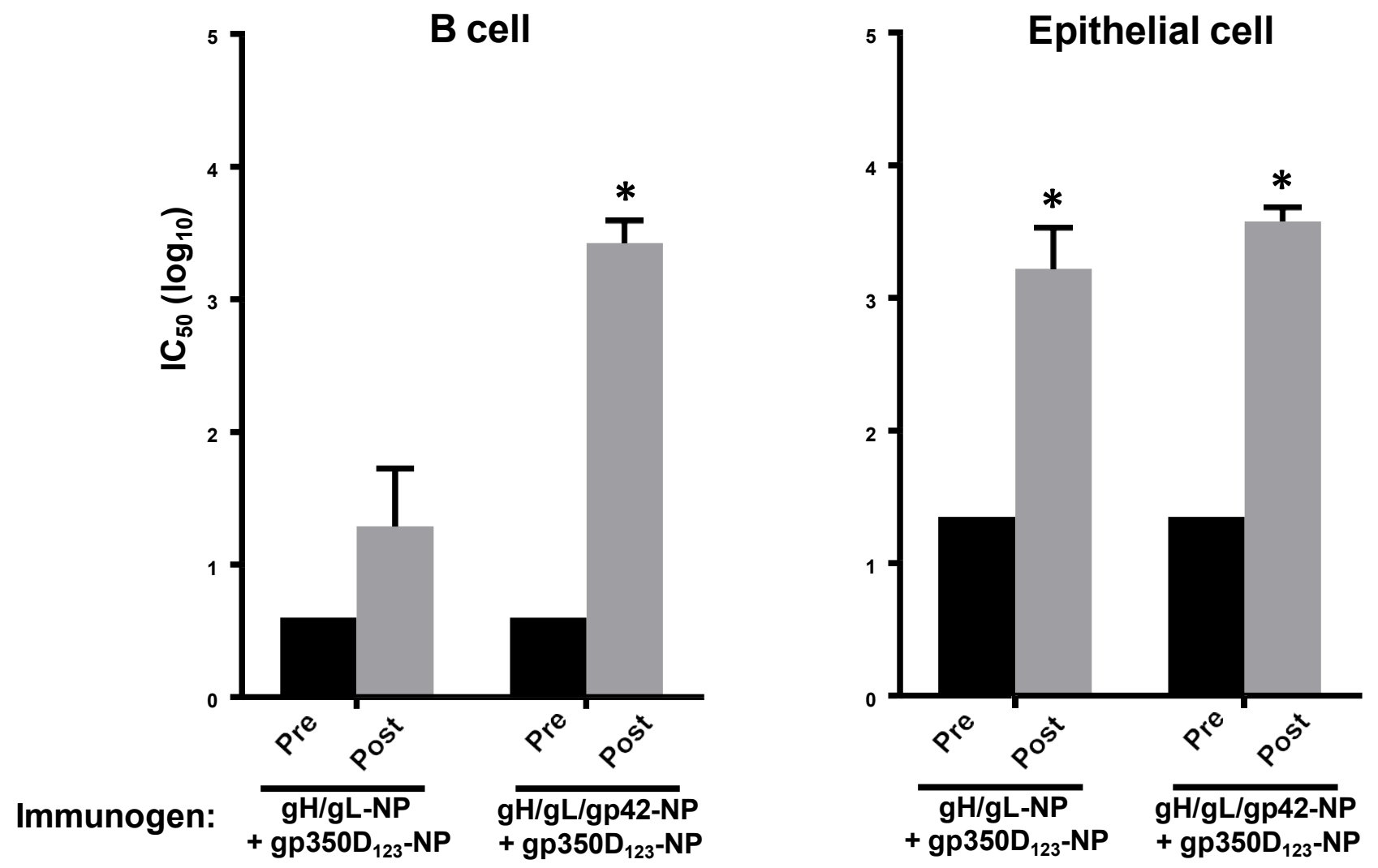

B

Non-human Primate (pre-immune)

B cell

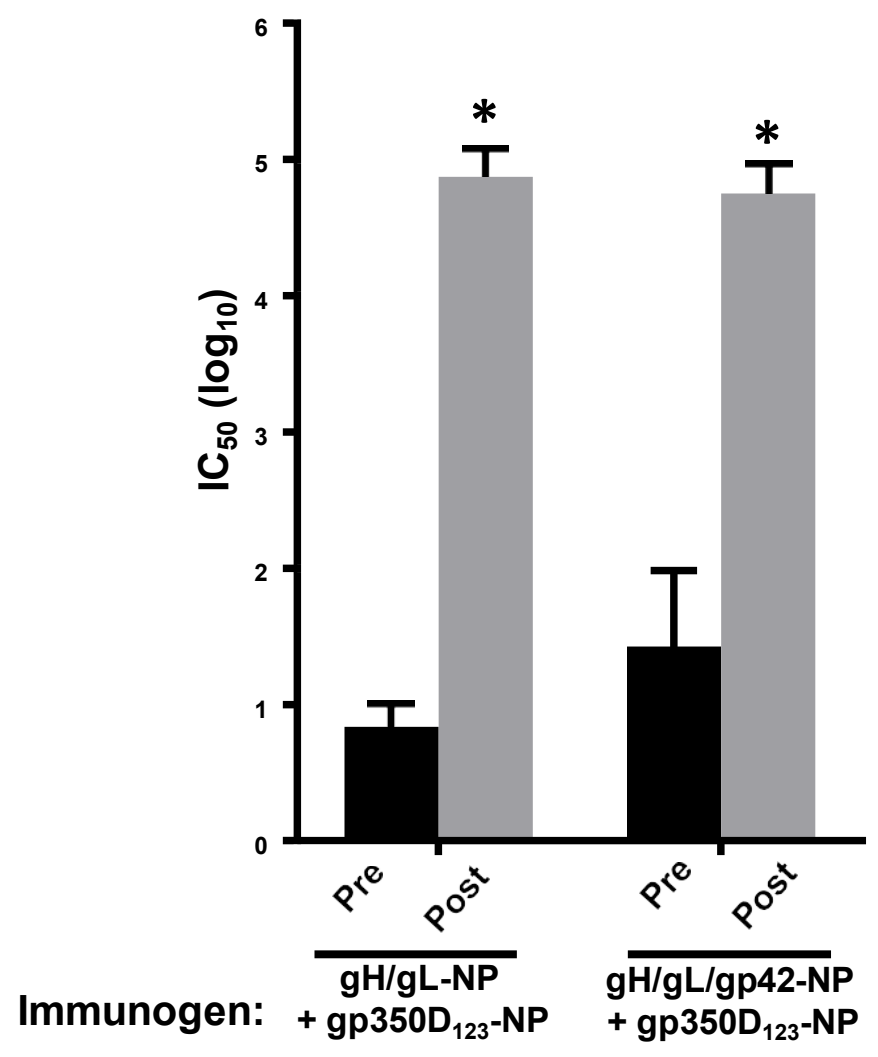

Epithelial cell

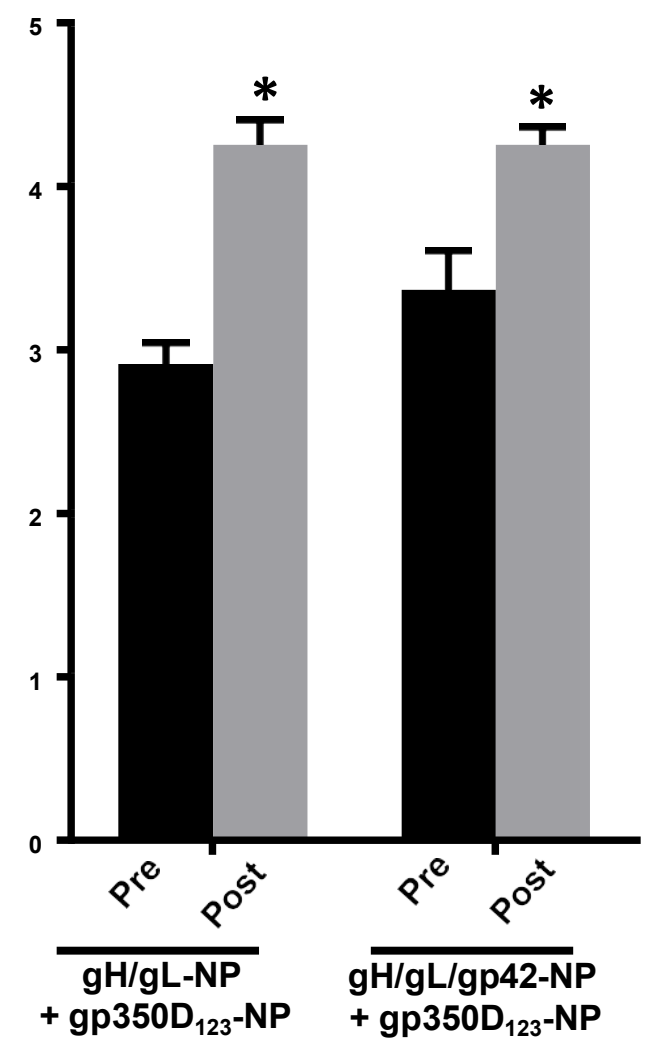


Figure 4

A

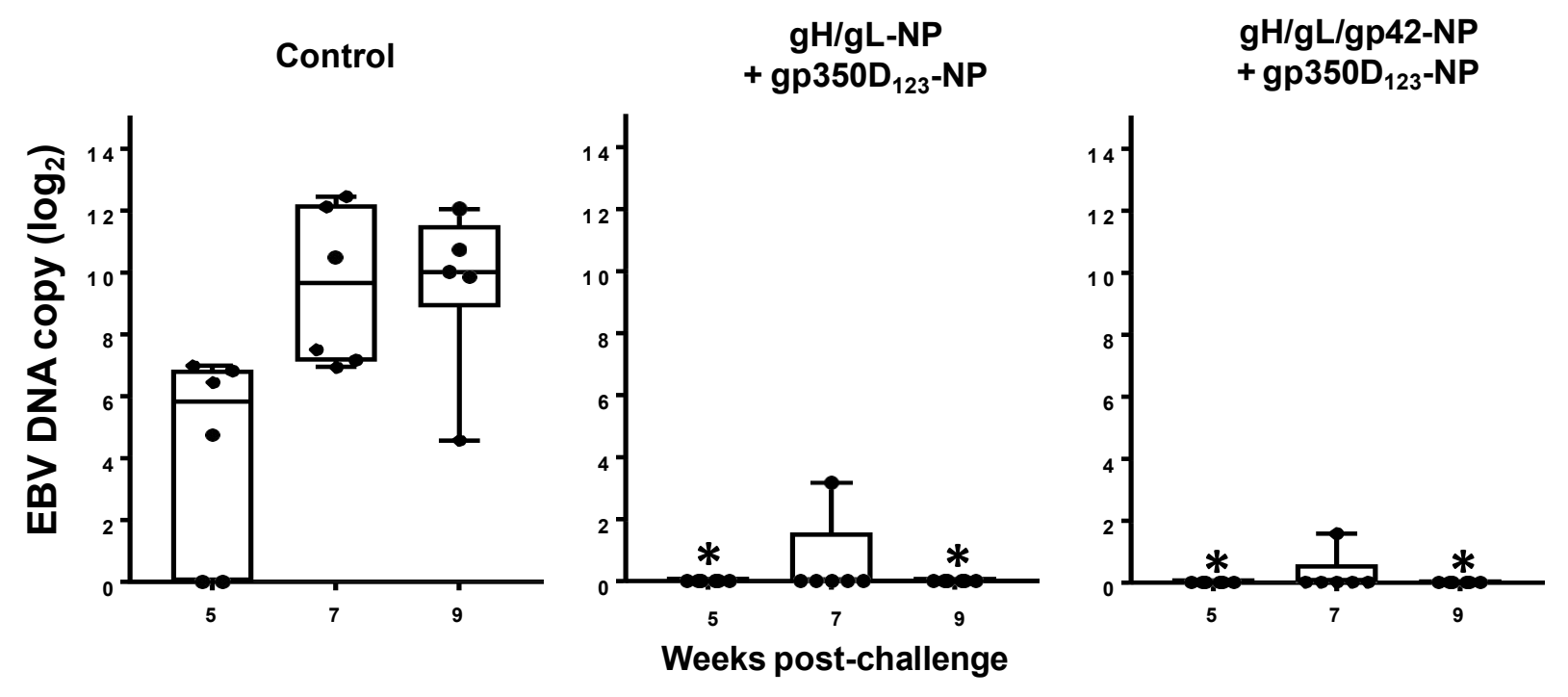

B

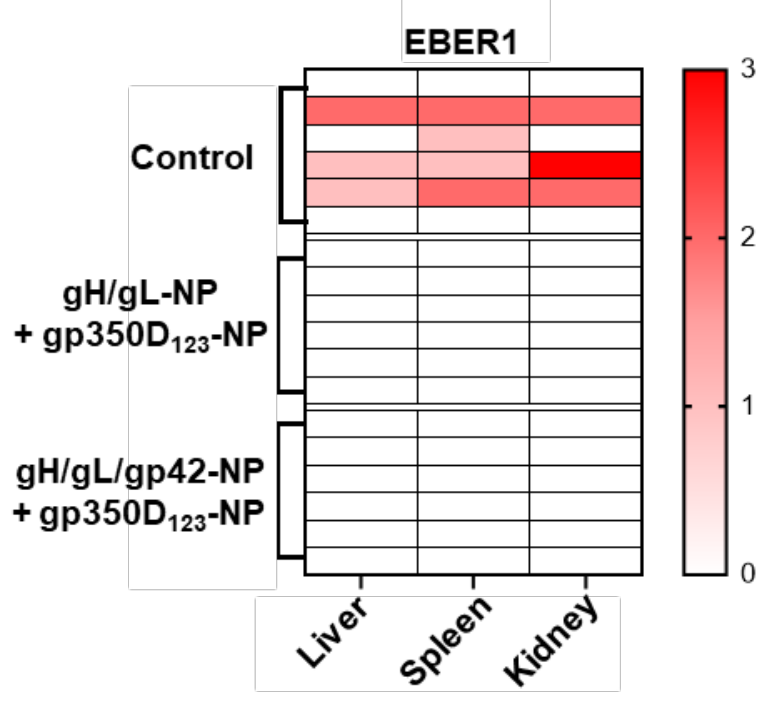


Immune

Control

H\&E

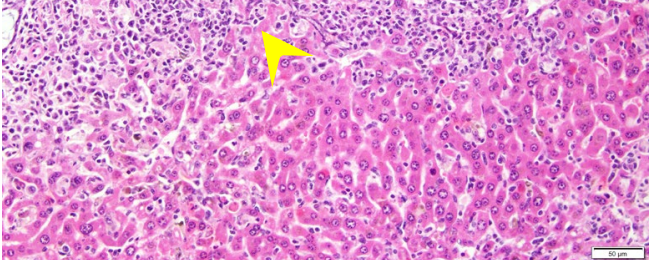

1.1.

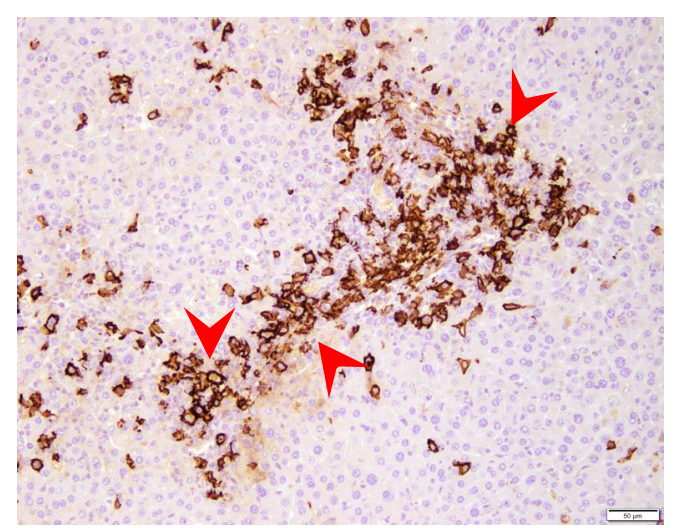

\section{CD20}

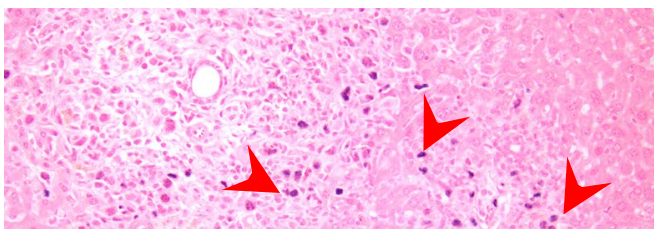

EBER

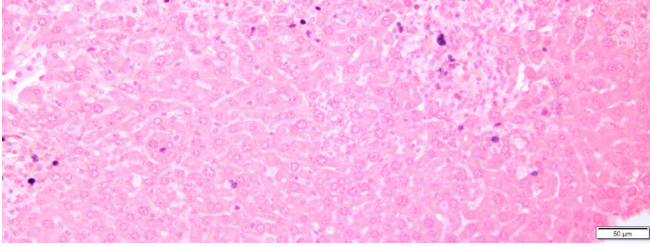

Immune

$\left(g H / g L / g p 42+g p 350 D_{123}\right)$
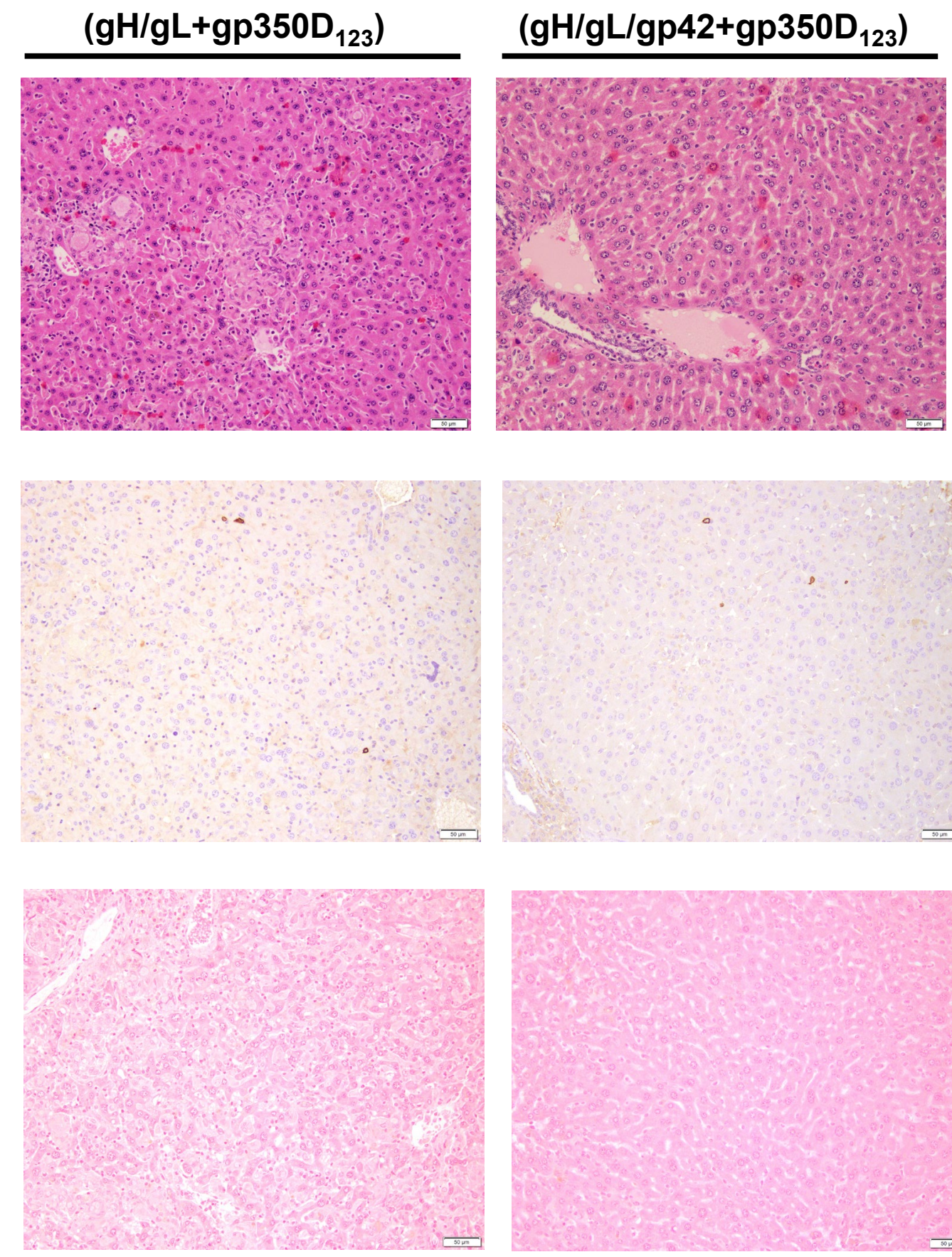

Figure 5
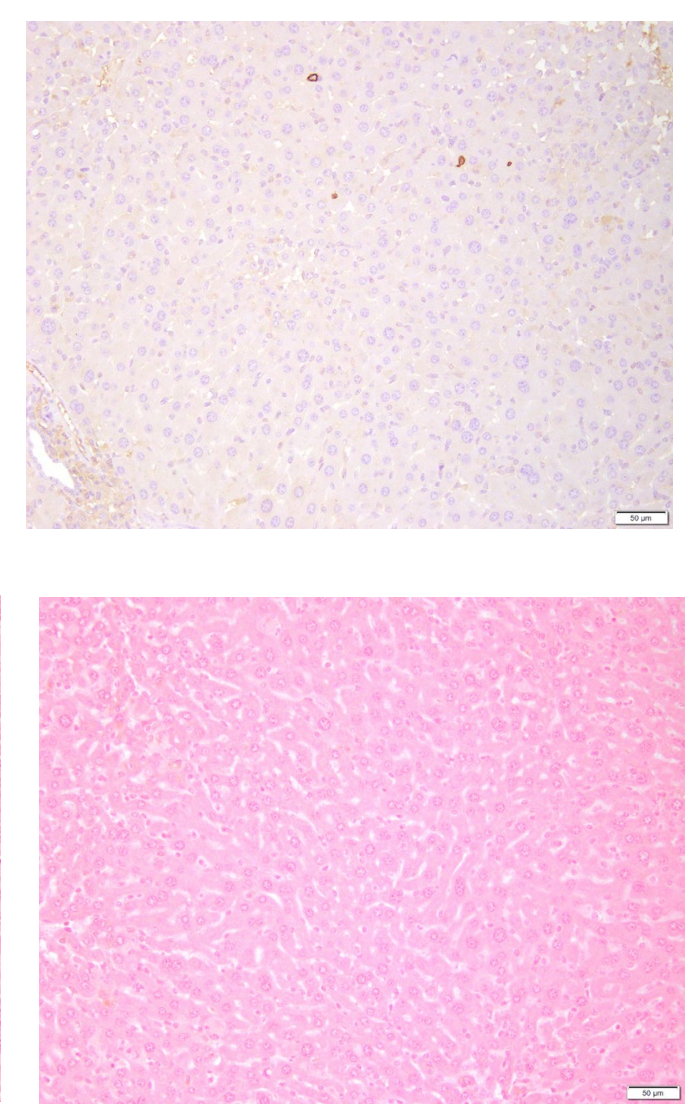
a

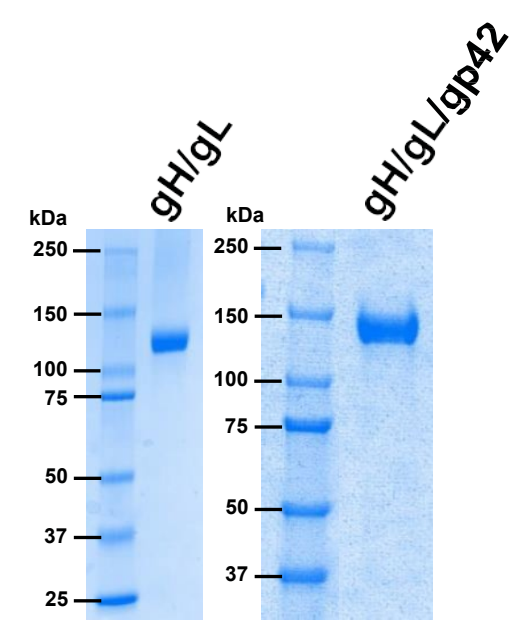

b

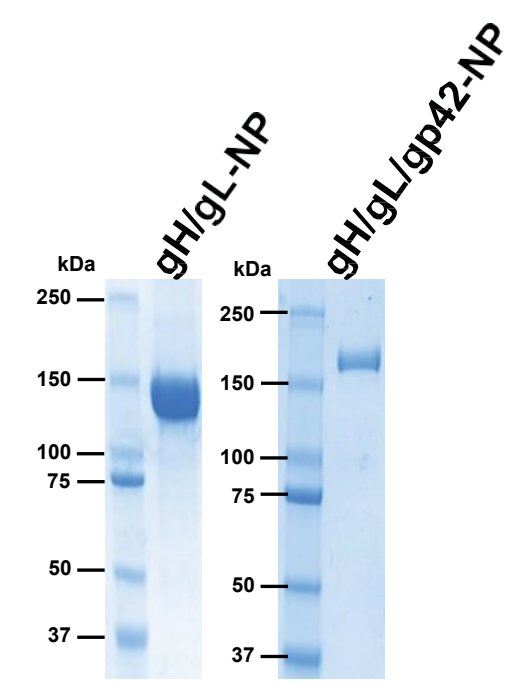




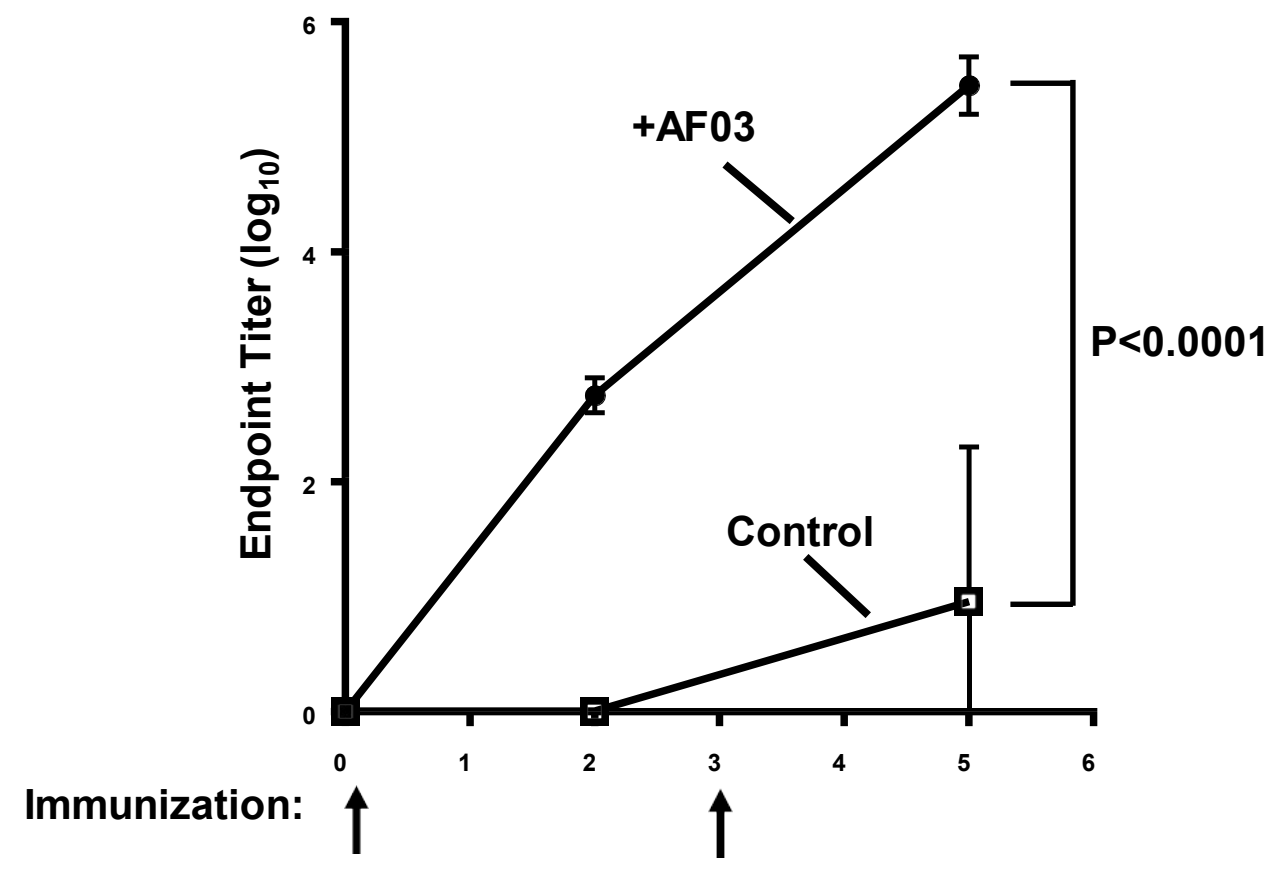

Week 
bioRxiv preprint doa: https://doi.org/10.1101/2022.01.18.476774; this version posted January 20,2022 . The copyright holder for this preprint

a

(which was not certified by peer review) is the author/funder. All rights reserved. No reuse allowgdyitopylefriegiotal Figure 3

Immunogen: $\quad$ gH/gL-NP

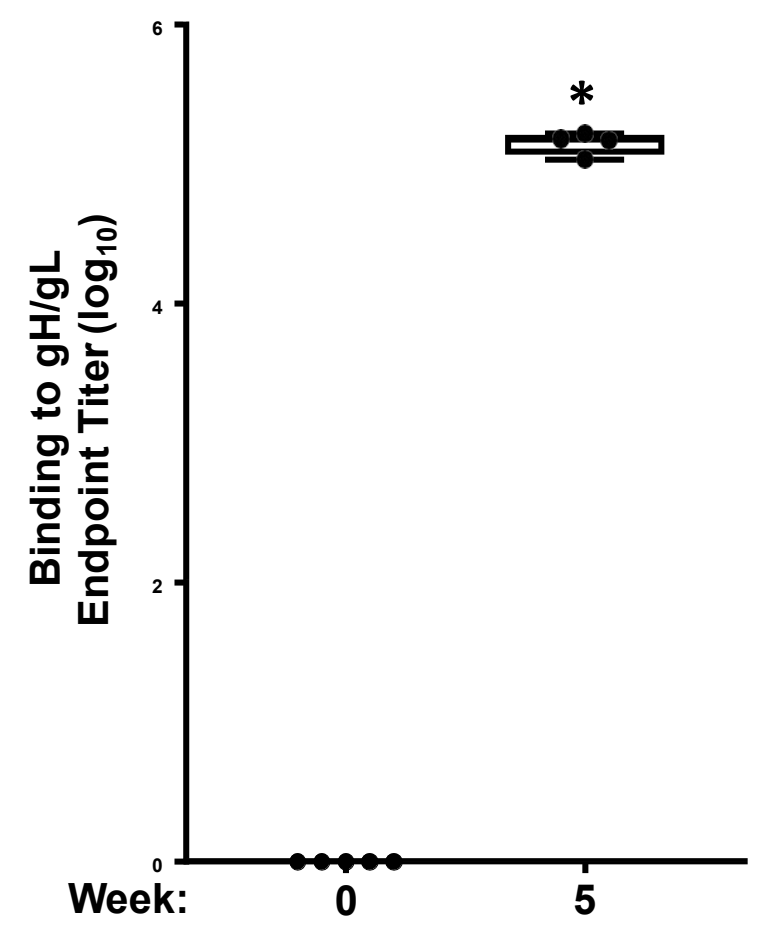

b

Immunogen:

$$
{\operatorname{gp} 350 D_{123}-\mathrm{NP}}
$$

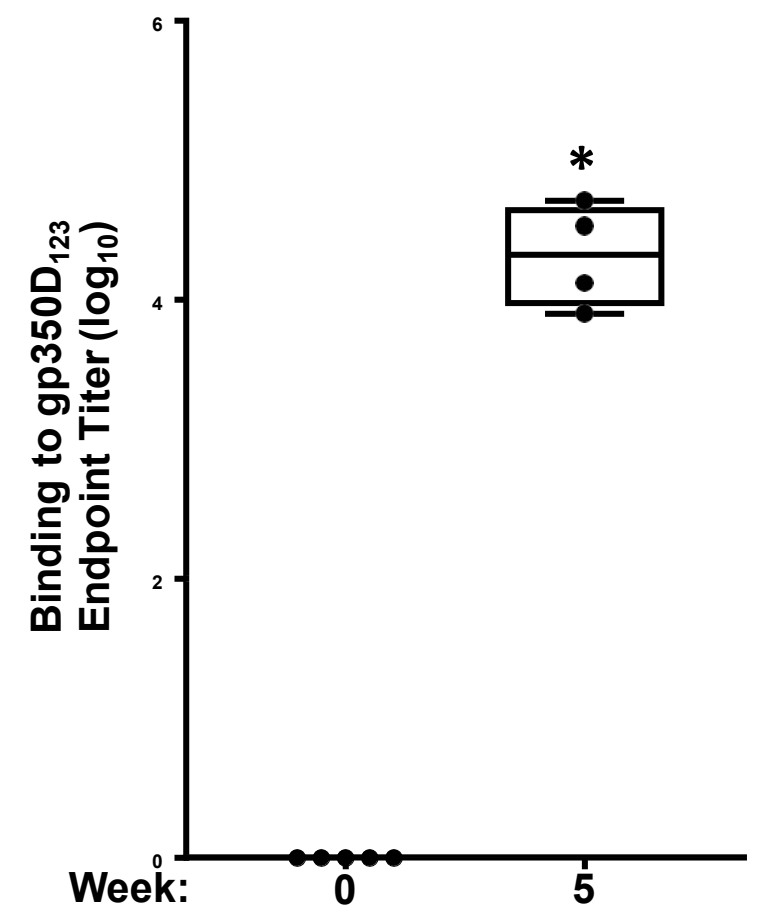

$$
g H / g L+g p 350 D_{123}-N P
$$

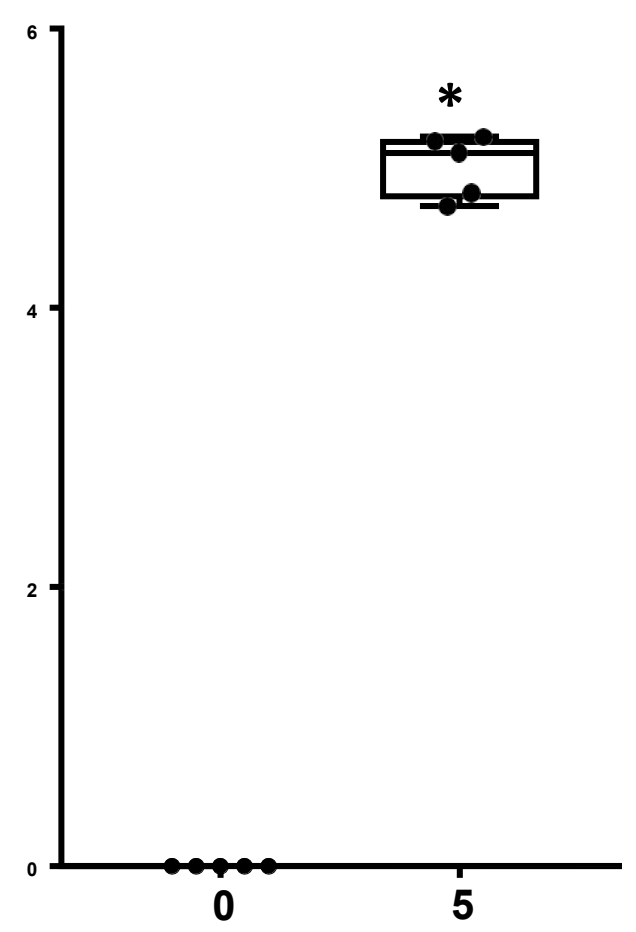

$$
g H / g L+g p 350 D_{123}-N P
$$

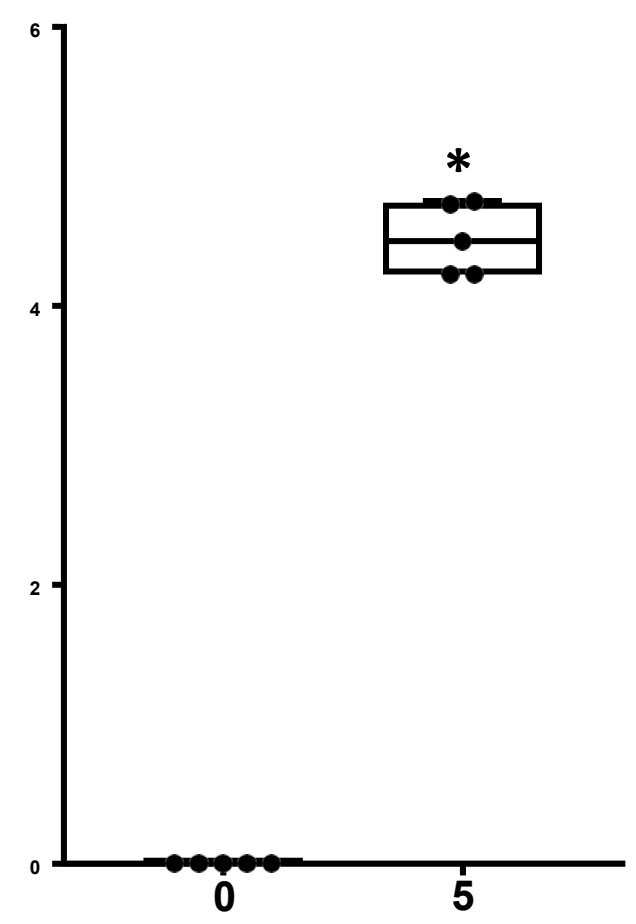


a

Immunogen:

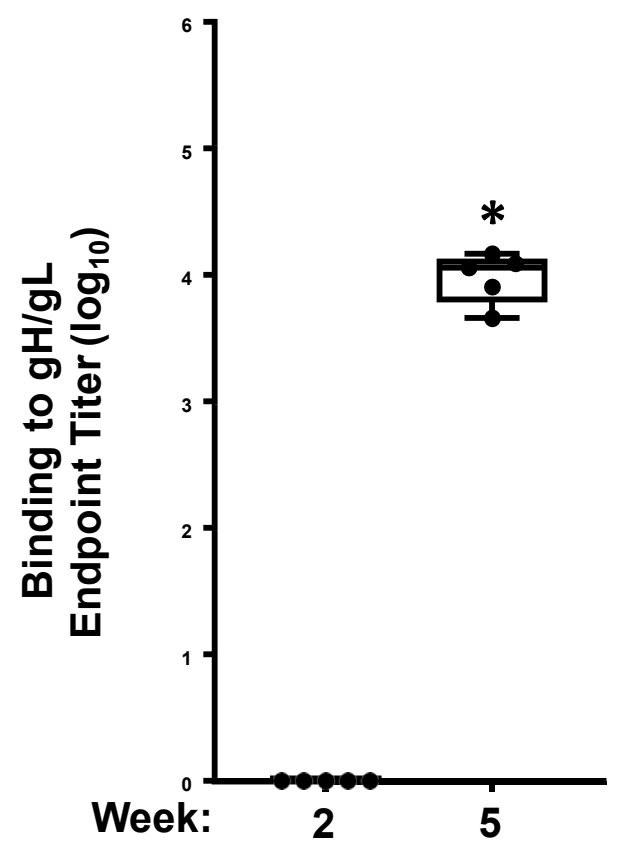

gH/gL/gp42-NP

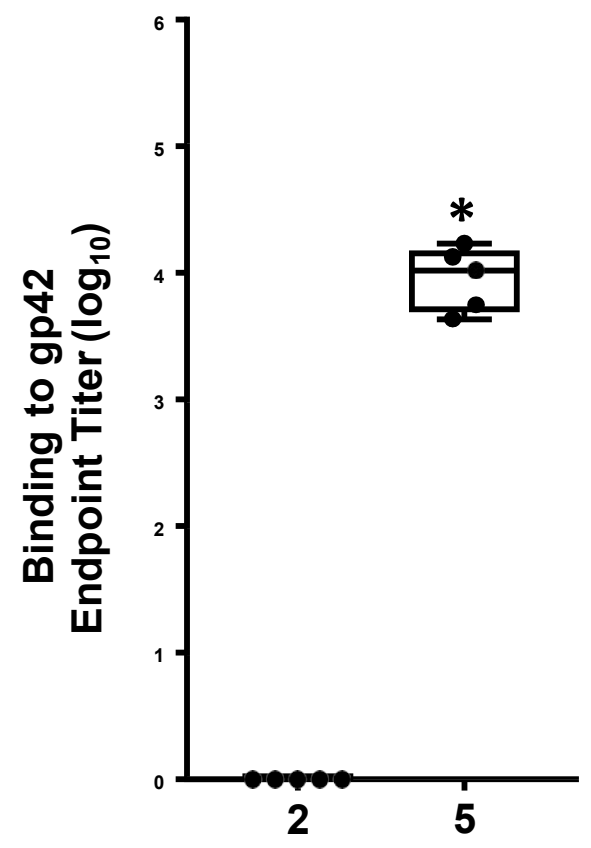

b

Immunogen:

$\mathrm{gH} / \mathrm{gL} / g \mathrm{p} 42+\mathrm{gp} 350 \mathrm{D}_{123}-\mathrm{NP}$
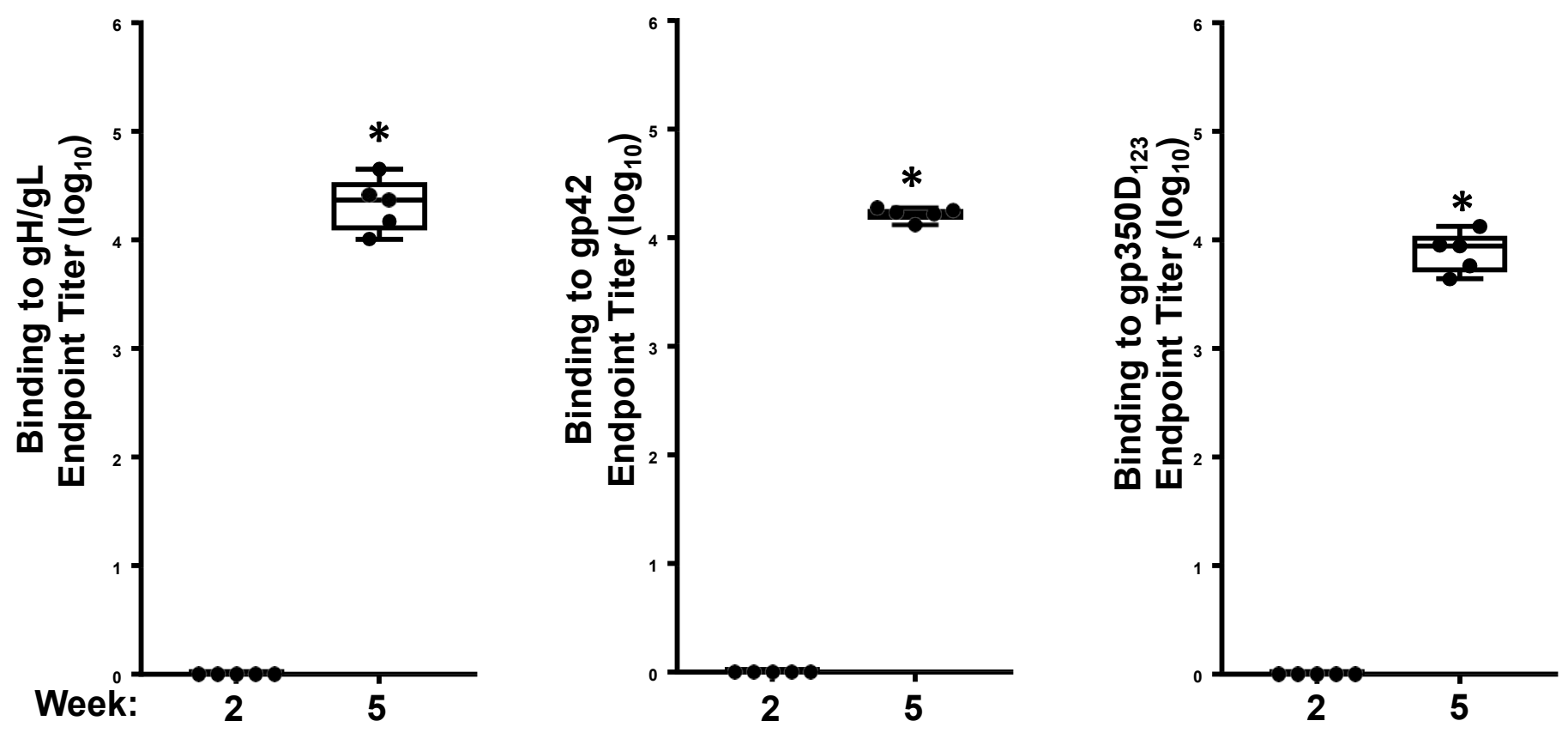


\section{Immunogen:}

$$
g H / g L-N P+g p 350 D_{123}-N P
$$
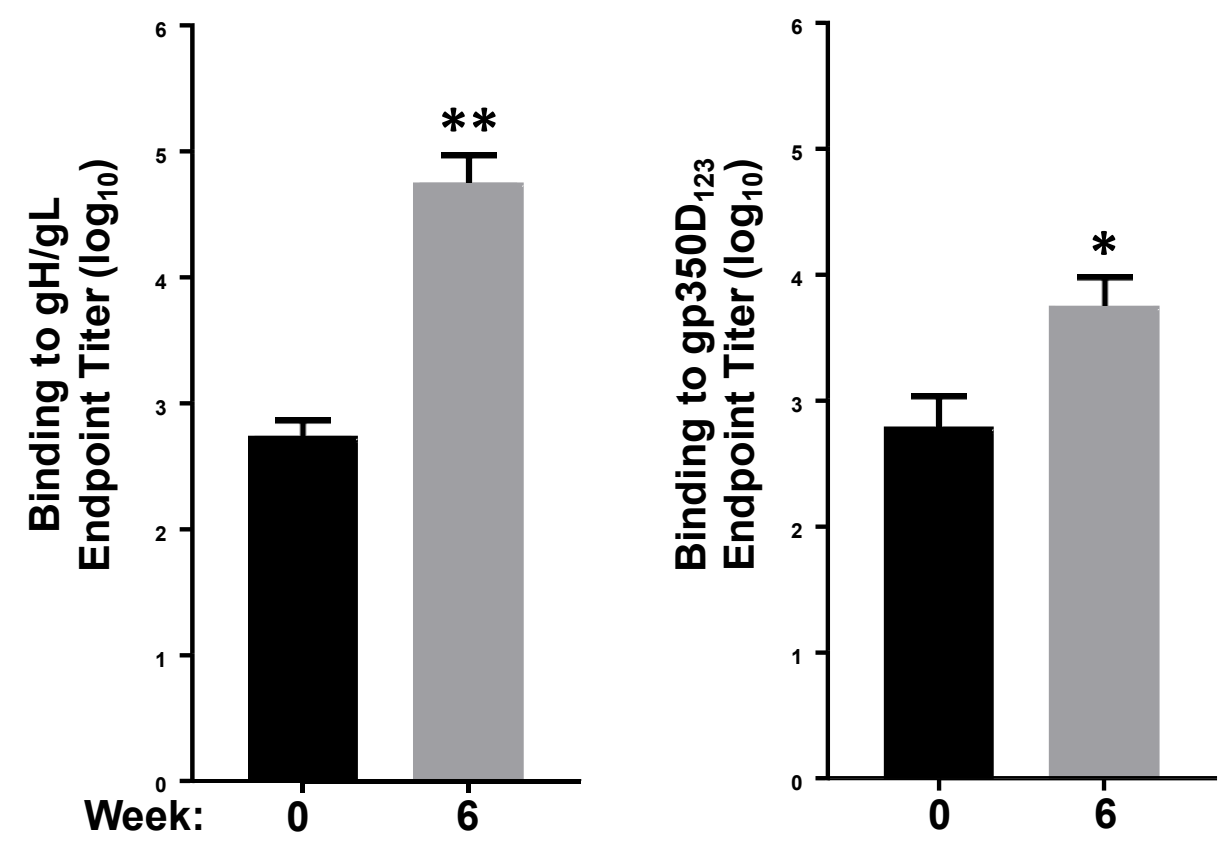

Immunogen:

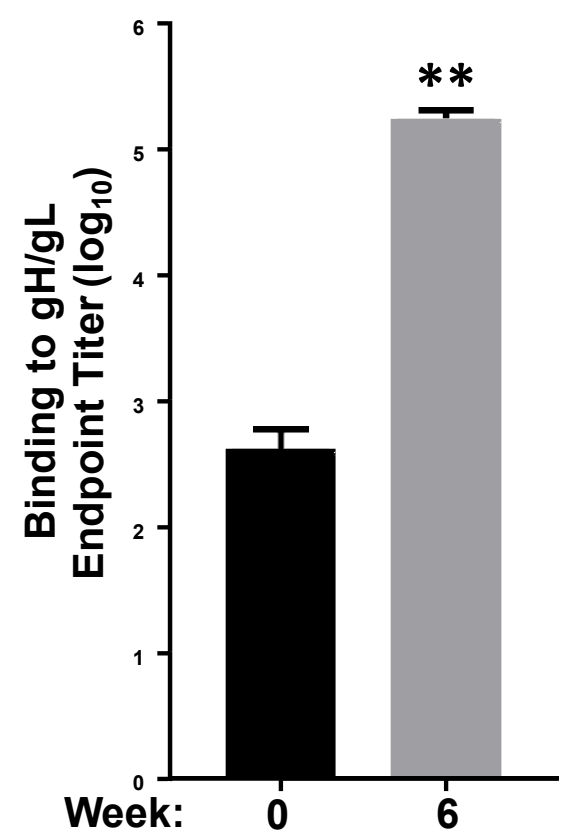

gH/gL/gp42-NP + gp350D $123-N P$

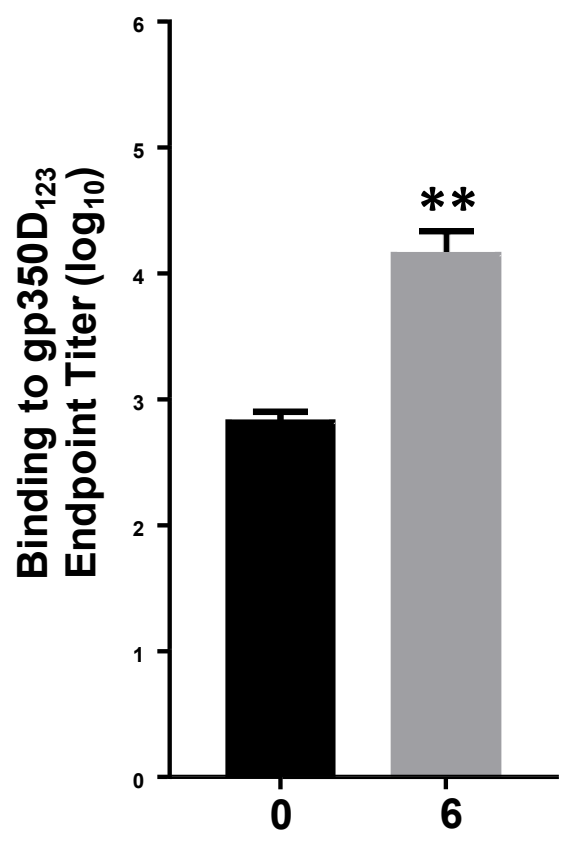

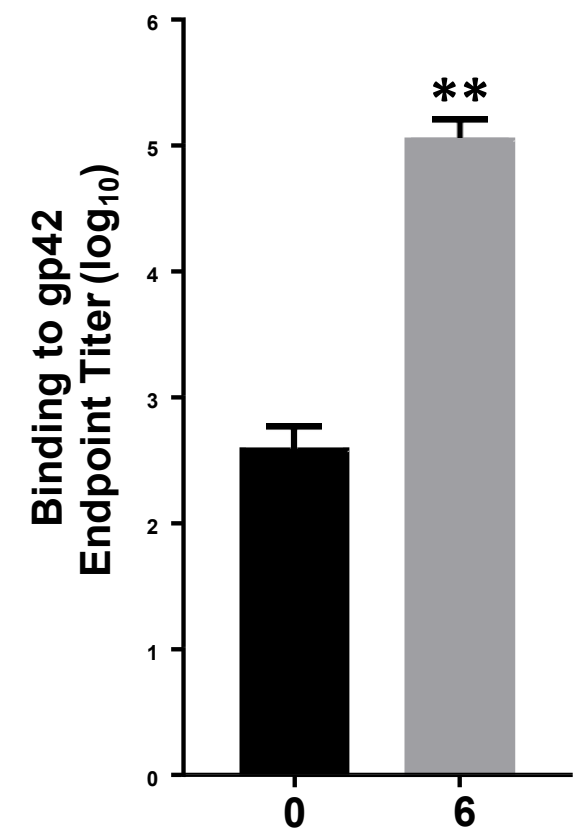


Immunogen:

gH/gL-NP + gp350D $123-N P$
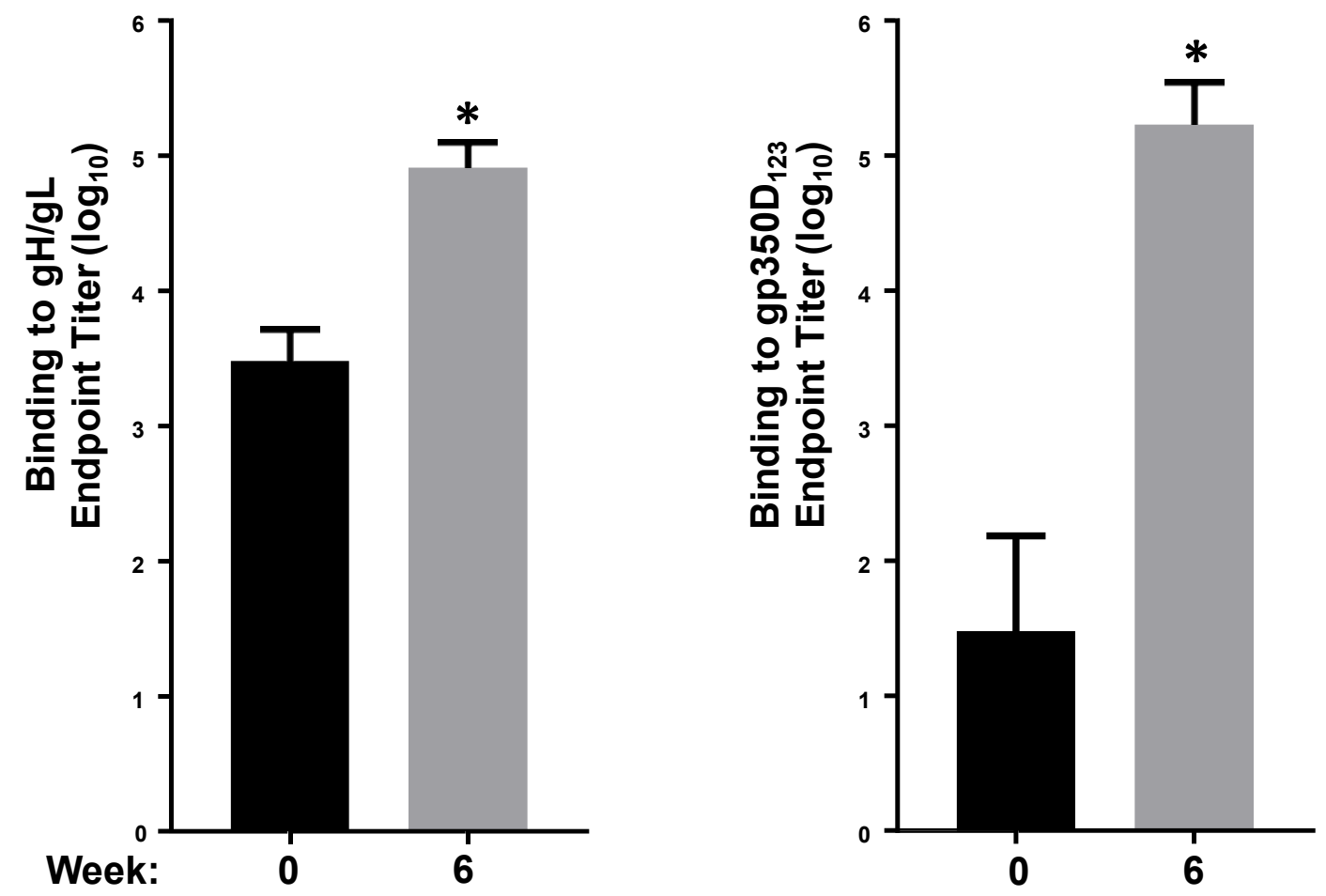

Immunogen:

gH/gL/gp42-NP + gp350D $123-N P$
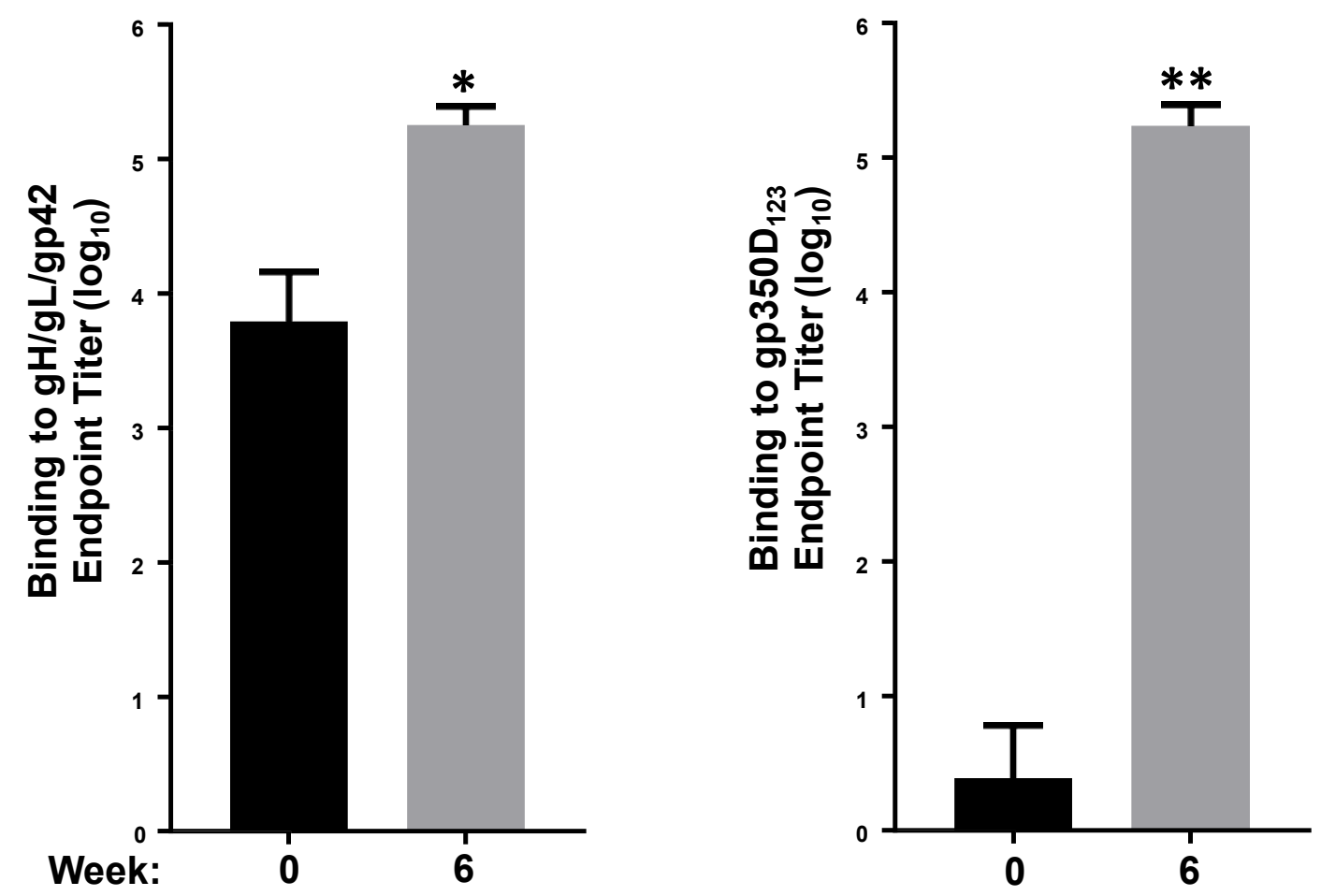
H\&E
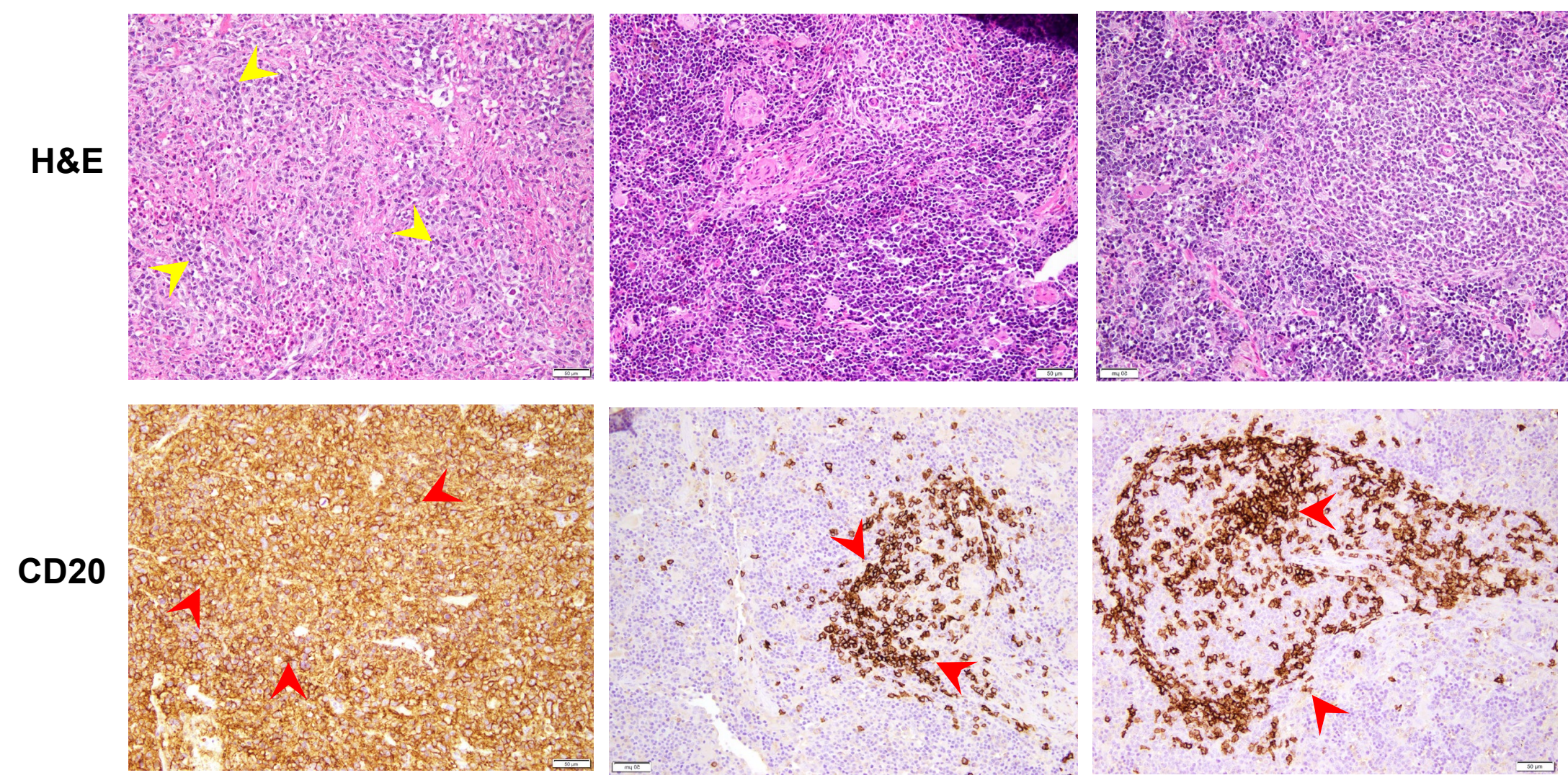

EBER
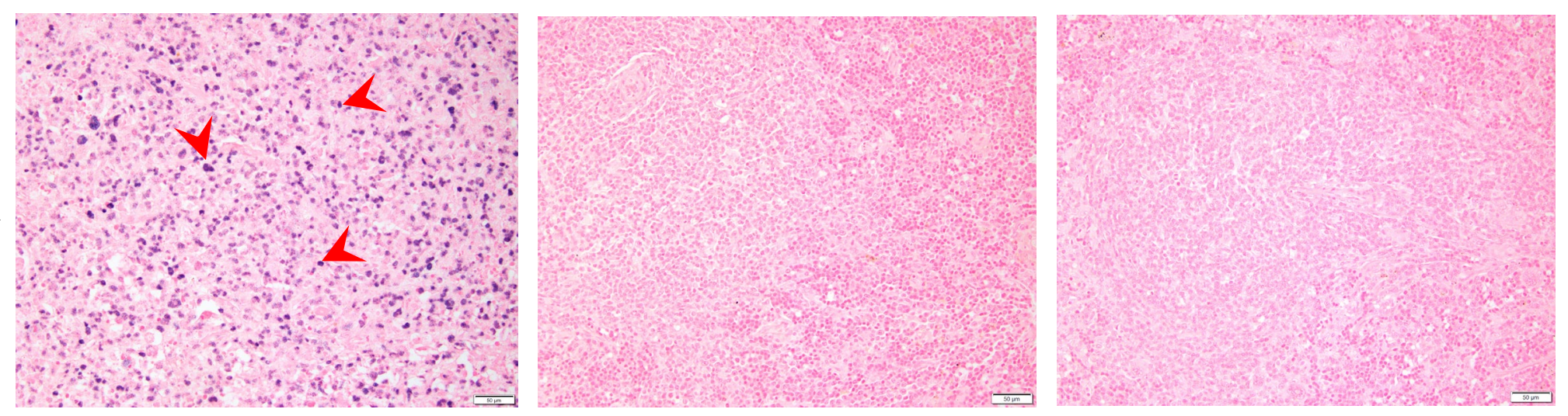
Immune

Immune

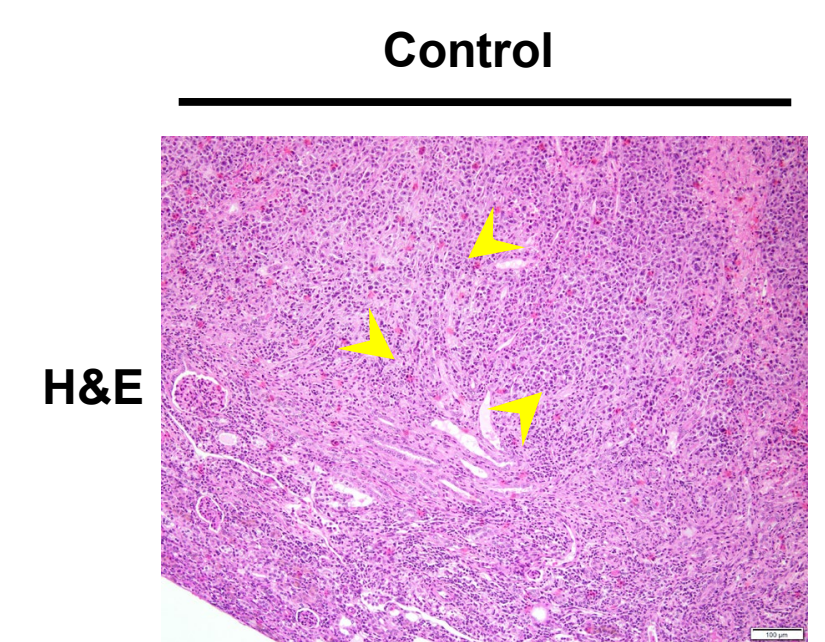

$\left(g H / g L+g p 350 D_{123}\right)$

(gH/gL/gp42+gp350D 123 )
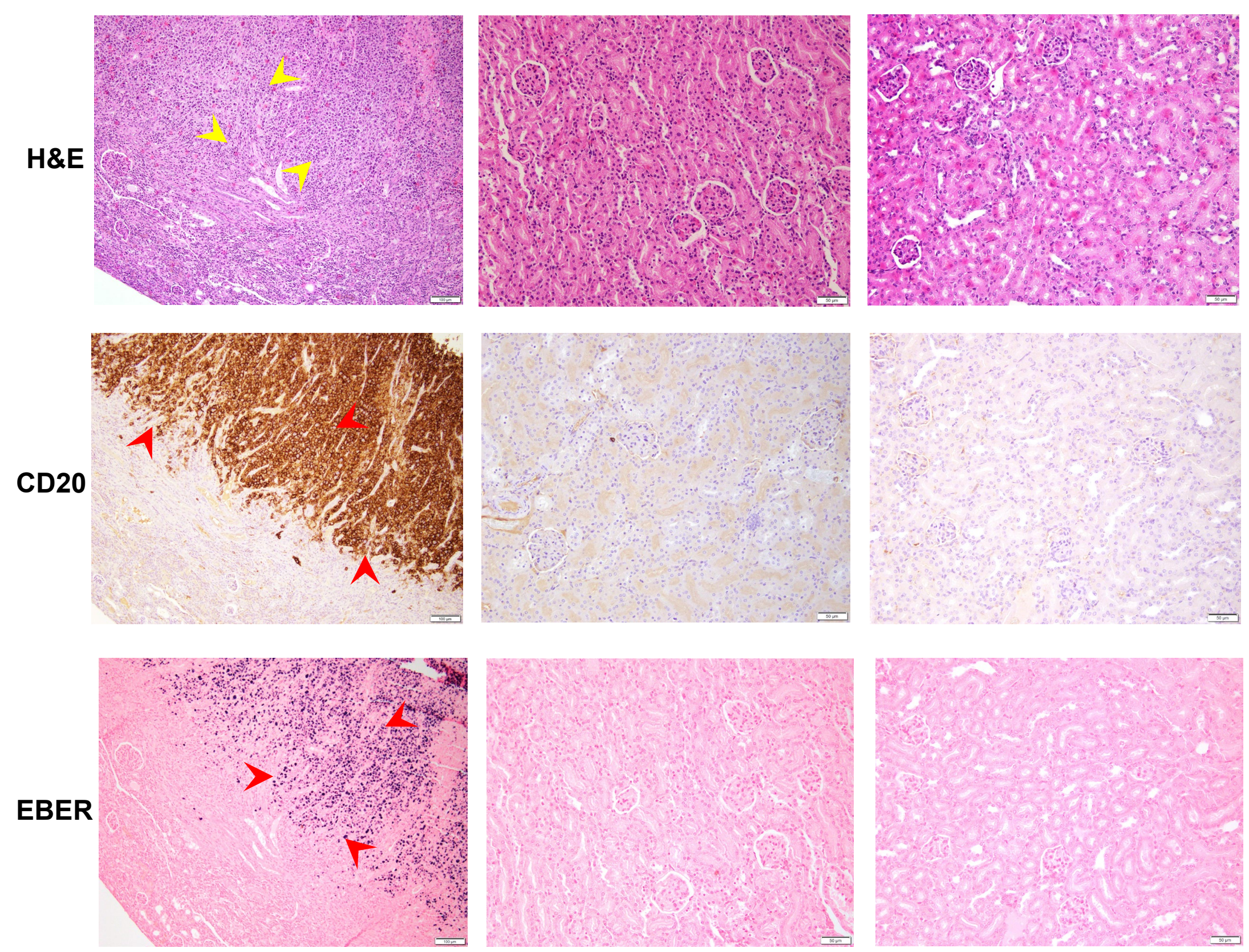

Supplemental Figure 7 
Supplemental Fig. 8

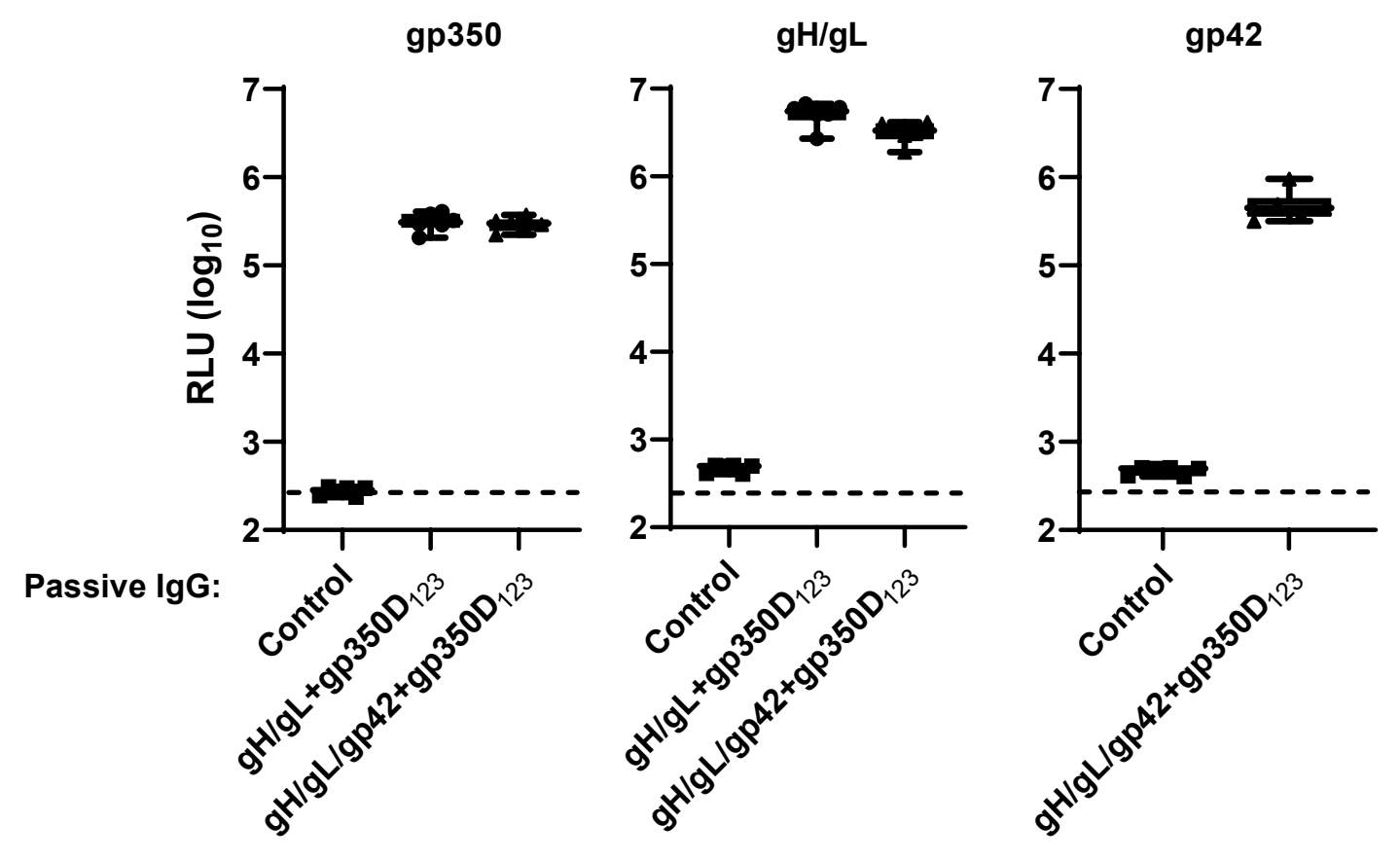

